\title{
Upper Aptian mixed carbonate-siliciclastic sequences from Tucano Basin, Northeastern Brazil: Implications for paleogeographic reconstructions following Gondwana break-up
}

\author{
Filipe Giovanini Varejão ${ }^{a, ~ *, ~ L u c a s ~ V e r i ́ s s i m o ~ W a r r e n ~ a, ~ J o s e ́ ~ A l e x a n d r e ~ d e ~ J e s u s ~ P e r i n o t t o ~}$, \\ Virgínio Henrique Neumann ${ }^{\mathrm{b}}$, Bernardo Tavares Freitas ${ }^{\mathrm{c}, \mathrm{d}}$, Renato Paes de Almeida ${ }^{\mathrm{c}}$, \\ Mario Luis Assine ${ }^{\text {a }}$ \\ a Instituto de Geociências e Ciências Exatas, Universidade Estadual Paulista, Avenida 24A, 1515, Rio Claro 13506-900, SP, Brazil \\ ${ }^{\mathrm{b}}$ Laboratório de Geologia Sedimentar e Ambiental (LAGESE), Departamento de Geologia, Universidade Federal de Pernambuco, Recife 50670-000, PE, Brazil \\ c Instituto de Geociências, Universidade de São Paulo, Rua do Lago, 562, Cidade Universitária, São Paulo 05508-900, SP, Brazil \\ ${ }^{\mathrm{d}}$ Faculdade de Tecnologias, Universidade Estadual de Campinas, R. Paschoal Marmo, 1888, Jd. Nova Itália, Limeira 13484-332, SP, Brazil
}

\section{A R T I C L E I N F O}

\section{Article history:}

Received 25 February 2016

Received in revised form

22 June 2016

Accepted in revised form 30 June 2016

Available online 1 July 2016

\section{Keywords:}

Serra do Tonã

Marizal Formation

Crato Formation

Cretaceous paleogeography

Microbialites

\begin{abstract}
A B S T R A C T
The evolution of the Cretaceous basins of the Brazilian northeastern hinterland was associated with the Gondwana rifting and opening of the South Atlantic Ocean. The first marine ingression in northeastern Brazil occurred in the late Aptian and was recorded as the Santana Group of the Araripe Basin, which is currently an isolated basin, located hundreds of kilometers away from the Brazilian marginal basins. Bellow the first upper Aptian marine deposits, an important section of fossiliferous limestone (Lagerstätte) was deposited and preserved in the Crato Formation transitioning upward into evaporites of the Ipubi Formation. The direction of the marine ingression is controversial, with several possibilities being suggested, mainly due to the absence of other areas of upper Aptian marine sections within the hinterland. Serra do Tonã is a sedimentary mesa with scarped edges where the upper part of the Marizal Formation crops out, displaying laminated limestones, litho- and chrono-correlated with those of the Crato Formation, is preserved. Therefore, this mixed upper Aptian section, at the North Tucano Basin (Serra do Tonã), is a unique occurrence of utmost importance to the definition of sedimentary events and paleogeographical reconstruction of northeastern Brazil during the late Aptian. A detailed stratigraphic analysis allowed the definition and characterization of two upper Aptian depositional sequences bounded by regional disconformities. Both sequences are dominantly transgressive and carbonatesiliciclastic in composition. The lower sequence comprises the basal portion of the Marizal Formation and consists of a succession of fluvial sandstones, ending on a laterally continuous thin interval $(<15 \mathrm{~m})$ of interbedded shales and limestones bearing exposure features and paleosols on the top. The limestones show a diversity of microfacies, including microbialites, organized in high-frequency deepening-upward cycles. The recognized sequence stratigraphic architecture resembles the lower part of the Barbalha Formation in the Araripe Basin, positioned in the same palynological zone, suggesting the correlation of the shale-carbonate interval in the Serra Tonã with the Batateira Beds in the Araripe Basin. The upper sequence also exhibits a fining upward pattern, with a vertical succession starting with sandstones and shales deposited in fluvial and deltaic environments, culminating upward in laminated limestones and lacustrine shales. The stratigraphic succession is very similar to the upper portion of the Barbalha Formation in the Araripe Basin, and the laminated limestones are lithostratigraphically classified as the Crato Formation. These limestones also comprise several microfacies, organized in a transgressiveregressive cycle with the maximum flooding surface positioned on relatively deep-water carbonates. Fluvial paleocurrent directions, which are similar to those of the Araripe Basin, suggest that both basins were part of the same continental paleodrainage, flowing to the south, where the South Atlantic proto-
\end{abstract}

\footnotetext{
* Corresponding author.

E-mail addresses: filipe.varejao@hotmail.com (F.G. Varejão), warren@rc.unesp.br (L.V. Warren), perinoto@rc.unesp.br (J.A.J. Perinotto), neumann@ufpe.br (V.H. Neumann), bernardotf@gmail.com (B.T. Freitas), rpalmeid@usp.br (R.P. Almeida), assine@rc.unesp.br (M.L. Assine).
} 
ocean was located. Fish fossils found in shales of the Marizal Formation, further south in the Central Tucano Basin and in the same stratigraphic interval of those of the lower sequence, were interpreted as marine forms. Indeed, some of them were considered to have Tethyan affinity, probably coming from an incipient Equatorial Atlantic gateway, supporting the interpretation based on the paleocurrents. The limestones at the top of the Serra do Tonã, which are also found in inselbergs in the Jatobá Basin, are relicts of a once extensive cover of Aptian carbonate deposits, now restricted because of uplifting and erosion events from the Late Cretaceous to the Cenozoic.

(c) 2016 Elsevier Ltd. All rights reserved.

\section{Introduction}

The Gondwana rifting and the opening of the South Atlantic Ocean created Cretaceous sedimentary basins that basically consist of rift (continental) and drift (marine) megasequences separated by an evaporitic transitional post-rift megasequence of late Aptian age (Chang et al., 1988, 1992). Although considered as a sag basin generated from thermal subsidence, several studies have found evidences of continued rifting tectonics during the transitional sequence (e.g., Karner et al., 2003; Chaboureau et al., 2013; Figueiredo et al., 2015).

The Recôncavo-Tucano-Jatobá (RTJ) rift system, which is located in northeastern Brazil, is part of the set of basins generated by the Gondwana break-up event (Fig. 1). The RTJ basins show a thick continental record deposited in asymmetrical half-grabens oriented in the north-south direction, with a reversal of depocenters associated with west-northwest transfer faults (Karner et al., 1992; Magnavita et al., 1994).

Unlike the continental marginal basins of the eastern Brazil, Late Cretaceous drift megasequence does not occur in the RTJ basins because they constitute an aborted rift system (Magnavita et al., 1994). Nevertheless, the transitional megasequence occurs throughout the RTJ rift system, comprising a continental succession, referred to as the Marizal Formation, with a maximum thickness of $300 \mathrm{~m}$ (Viana et al., 1971). The Marizal Formation is considered as late Aptian in age (Viana et al., 1971), based on palynomorphs positioned in the P-270 palynological zone, P-270.2 subzone (Sergipea variverrucala biozone) (Regali, 2000). This unit consists mainly of sandstones and conglomerates, attributed to be deposited in fluvial and alluvial fan systems, with localized exposures of finegrained siliciclastic deposits and lacustrine carbonates (Magnavita et al., 1994; Lima and Vilas Boas, 2000; Figueiredo et al., 2015).

Upper Aptian carbonate-siliciclastic strata occur only locally in the basins of the RTJ system (Braun, 1966) as residual relief over the Marizal Formation, preserved from the Cenozoic erosion events (Fig. 1). There are upper Aptian laminated limestones in the Tucano Basin correlated with the limestones of the Crato Formation (Braun, 1966) in the Araripe Basin, which are the most important and representative Cretaceous Lagerstätte in Brazil (Martill et al., 2007a). Therefore, knowledge of this system stratigraphy is critical to the reconstruction of the geological history and paleogeography of the Brazilian northeastern hinterland during the Aptian.

In the North Tucano Basin, excellent outcrops are found on Serra do Tonã, which is geomorphologically a mesa with a flat top with $130 \mathrm{~km}^{2}$ with scarped edges that is approximately $100 \mathrm{~m}$ higher than its surroundings. Its stratigraphic succession was studied by Rolim (1984), who described lacustrine carbonates at the top of the elevation, overlapping the fluvial sandstones of the Marizal Formation. In addition to the limestones on top of the plateau, Almeida-Filho et al. (2002) described another level of limestones, separated from the upper limestones by approximately $80 \mathrm{~m}$ of fluvial sandstones. This lower carbonate level was for the first time recognized by Ghignone (1978) in the Central and South Tucano basins associated with siltstones and shales with ostracodes and fish fossils.

As an important relict of widespread carbonate deposition potentially correlating several sedimentary basins in northeastern Brazil, the Serra do Tonã record is here investigated. To elucidate the nature of the preserved succession, this study aimed to identify its depositional sequences, establish the vertical array of sedimentary facies and interpret the corresponding depositional environments, defining paleogeographical elements, such as sedimentary provenance and depositional dip, and integrating the isolated Serra do Tonã record with the regional paleogeographical context of the Cretaceous Brazilian Northeast.

\section{Materials and methods}

The Serra do Tonã area was mapped in order to identify and locate the sedimentary units that constitute the carbonatesiliciclastic sections. For this purpose, LANDSAT satellite images and digital elevation models built with Shuttle Radar Topography Mission/National Aeronautics and Space Administration (SRTM/ NASA) data were interpreted. The interpretations were validated and adjusted based on outcrop and vertical profile data, allowing the tracing of contacts and the delimitation of the two carbonate units, both considered here as guide layers (Fig. 2).

Two detailed representative vertical profiles of the stratigraphic succession were measured in drainages and hill escarpments near Salgado do Melão and São Saité settlements (State of Bahia), and sedimentary facies associations were described. Paleocurrent data, obtained from foreset dip directions of sandstone cross strata, were statistically analyzed and presented in the form of iso-frequency rose diagrams. Data from wells 2-TN-ST-03a-BA and 2-TN-SM-BA, which were drilled in the area to evaluate the occurrence of the units in the subsurface, were also analyzed. The wells had continuous coring, recovering $52 \mathrm{~m}$ and $99 \mathrm{~m}$, respectively.

Carbonates were properly sampled and analyzed using optical (Zeiss Axio Imager A.2 binocular petrographic microscope) and scanning electron microscopy (SEM) techniques at the Center for Applied Geosciences in Oil - Centro de Geociências Aplicadas ao Petróleo, UNESpetro, São Paulo State University, UNESP (model Zeiss EVO ${ }^{\circledR}$ MA 15, operated at EHT $20 \mathrm{kV}$ and 100 Pa pressure). The carbonate microfacies were classified according to Dunham (1962), Demicco and Hardie (1994) and Riding (2000).

\section{Depositional sequences}

The Aptian succession in the North Tucano Basin consists of two depositional sequences bounded by regional disconformities (Fig. 3). Depositional Sequence 1 (DS1; bottom) rests on an erosional, locally angular, unconformity over syn-rift Lower Cretaceous (Barremian) deposits and is composed of an approximately 150-meter-thick sand-dominated section ending on a carbonateshale interval ranging from 5 to $15 \mathrm{~m}$ in thickness. The basal portion of the sequence is not present in the Serra do Tonã plateau 

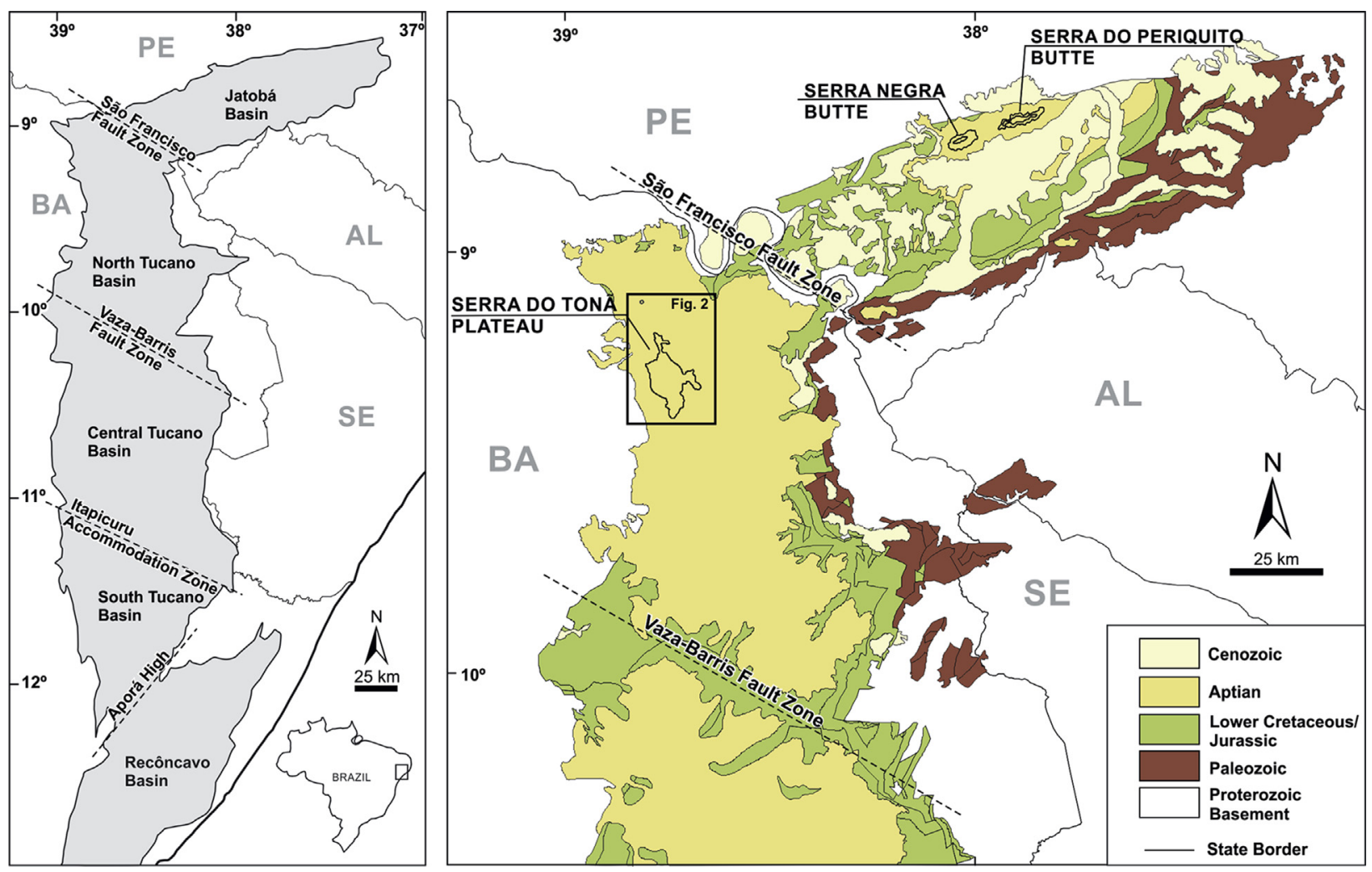

Fig. 1. Recôncavo-Tucano-Jatabá rift system (left) and schematic geological map showing the study area (right).
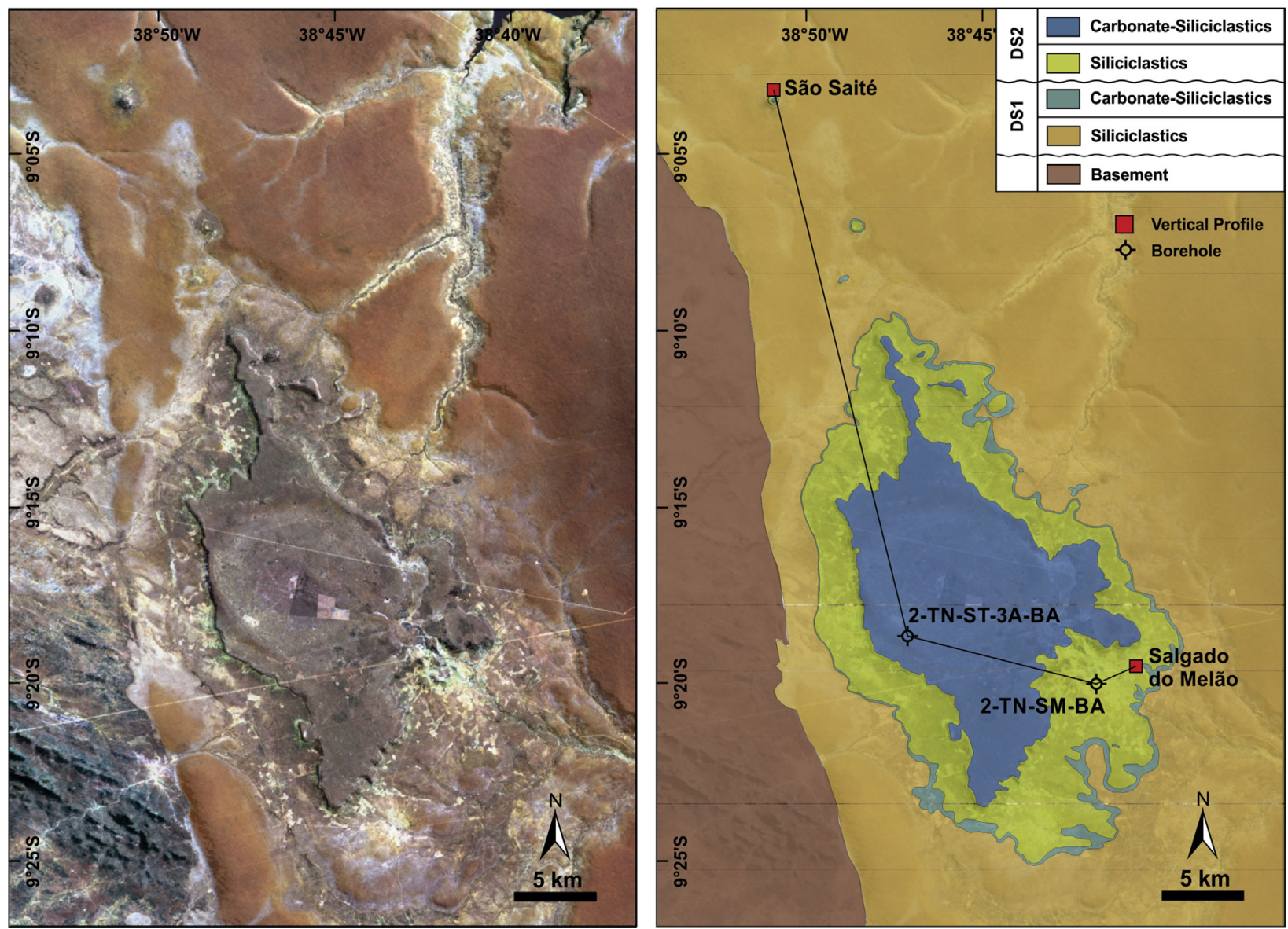

Fig. 2. Geological map of Serra do Tonã showing the locations of Salgado do Melão and São Saité settlements and the vertical profiles, as well as the drilled wells. 


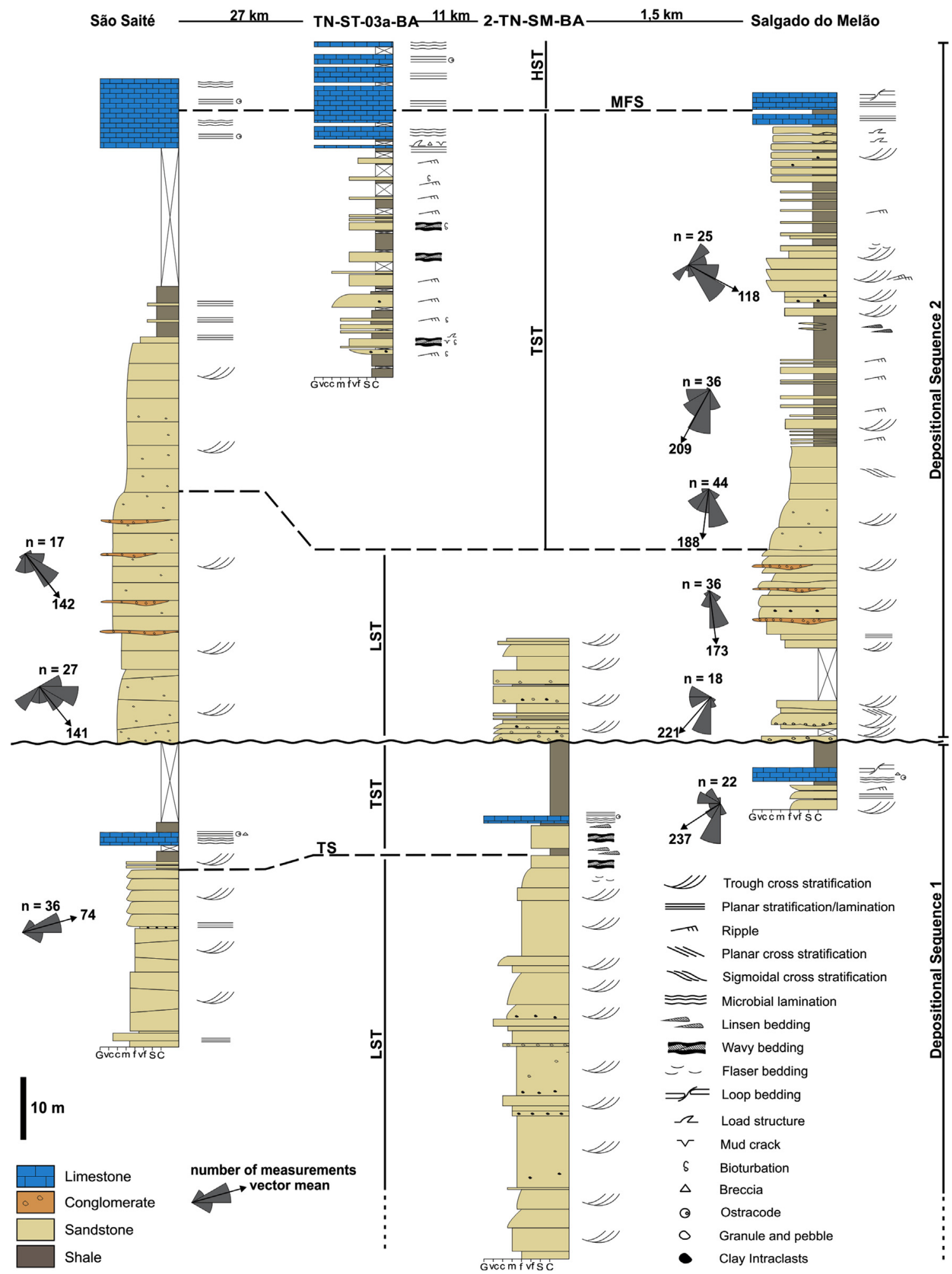

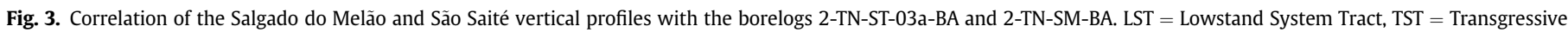
System Tract, and HST $=$ Highstand System Tract, MFS = Maximum Flooding Surface, TS = Transgressive Surface.

area, but several outcrops are present in the southern portion of North Tucano Basin. The Depositional Sequence 2 (DS2; top), is also sand-dominated (60 meter-thick) at the bottom and progressively richer in mud-dominated intervals (50 meter-thick) towards the top, ending with $20 \mathrm{~m}$ of laminated limestones interbedded with shales. The boundary between the two sequences is a regional disconformity marked by a non-depositional period and the formation of paleosol.

The lower DS1 succession crops out throughout the North Tucano Basin, where it is mapped as the Marizal Formation. This interval is composed of quartz to feldspathic, fine to very coarse, mostly poorly sorted white to locally reddish sandstones with 

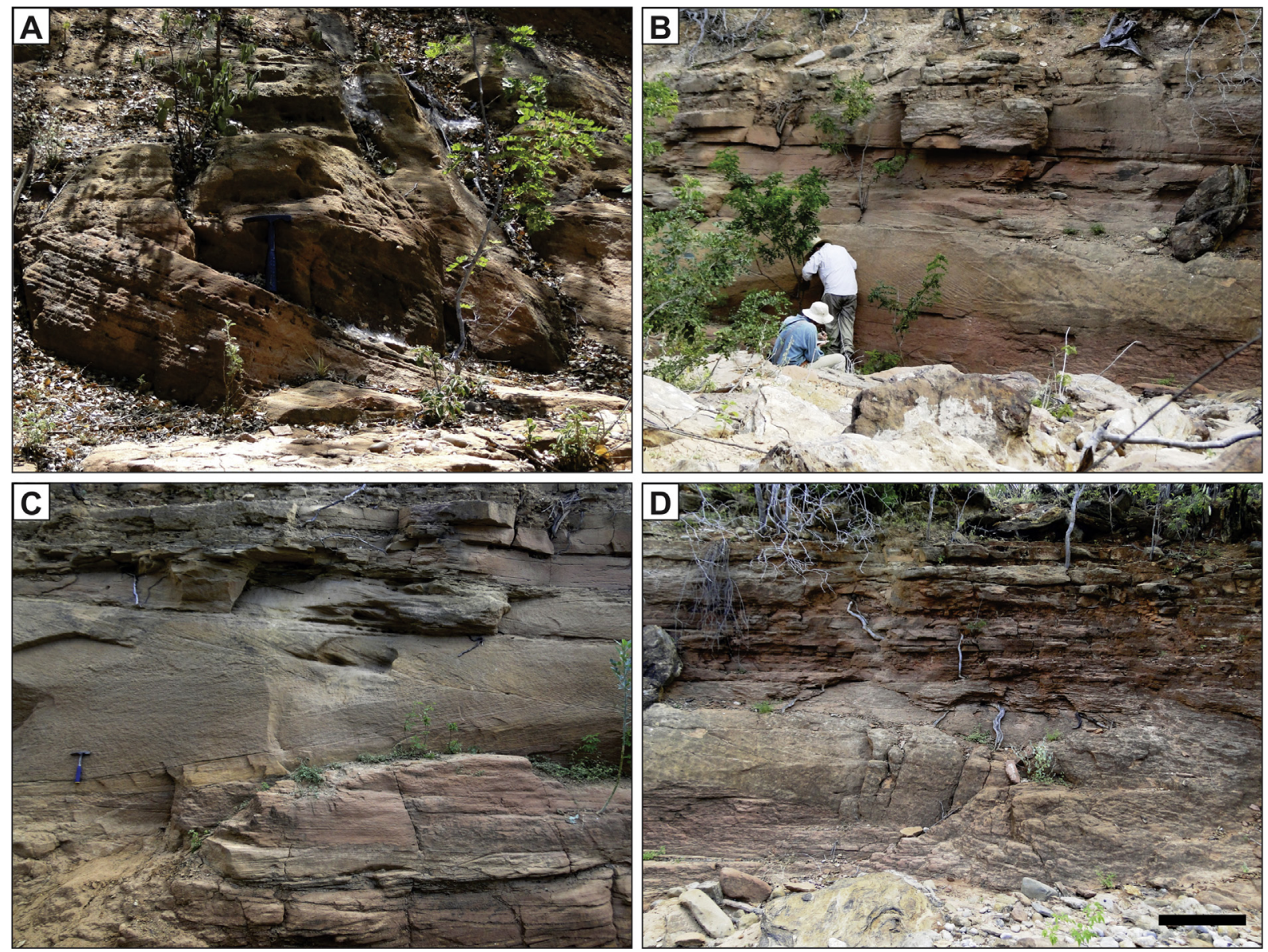

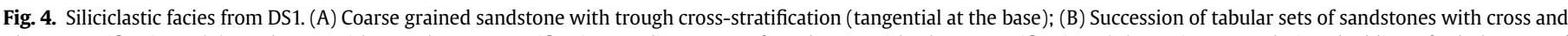

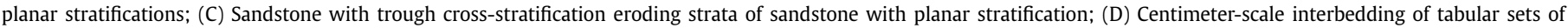
sandstones with shales, above sandstones with trough cross-stratification. Scale bar is $50 \mathrm{~cm}$ and hammer is $279 \mathrm{~mm}$ long.

angular to sub-rounded grains, as well as granules and pebbles dispersed or aligned on the foresets (Fig. 4A). Strata sets are decimetric, tabular and/or cuneiform, exhibiting trough crossstratification in the lower portion of textural fining cycles, and plane-parallel stratification at the top of the cycles (Fig. 4B-C). Thin beds of clayey siltstones occur locally on top of the fining upward successions (Fig. 4D). DS1 paleocurrents (101 samplings) in the Serra do Tonã area show east-southeast paleoflow (mean azimuth toward $105^{\circ}$ ).

The sequence is overlapped by a mixed carbonate-siliciclastic section with thickness ranging from 5 to $15 \mathrm{~m}$, which continuously skirts the foothills of Serra do Tonã (Fig. 2). The transition is marked by increasingly fine and micaceous sandstones, locally interbedded with gray siltstones and claystones. The carbonate facies mainly comprise Mg-rich limestones with wavy to irregular thin laminations organized in beds usually displaying a mean thickness of $2 \mathrm{~m}$ (Fig. 5C-D). These deposits are commonly quite ferricritized and silicified at the surface (Fig. 4). Reddish-brown siltstones of varying thickness overlay the limestones (Fig. 5A). Pedogenetic features can be observed at the top of the mixed carbonate-siliciclastic succession, including slots and venules filled by calcium carbonate (Fig. 5B). Variations in the thickness and presence of paleosols are controlled by the disconformity that limits the two depositional sequences.

DS2 starts with coarse to very coarse sandstones with trough cross stratification limited at the base by an erosional contact truncating the DS1 (Fig. 5A-B). Decimeter-thick discontinuous levels of oligomictic conglomerates (mainly with quartzites, gneisses and quartz veins pebbles) are interbedded with sandstone sets. Overall, the succession shows fining-upward architecture (Fig. 3). The sandstones vary from fine to very coarse, often containing pebbles and granules dispersed or concentrated on the foresets (Fig. 6A). This facies occur in tabular and/or cuneiform cross-strata sets decimeter to meter-scale thick, with trough cross stratification and minor planar cross stratification. Clay clasts sometimes occur at and/or near the base of some cross-strata sets. Fine sandstones, centimeter to decimeter-thick, occur interbedded, displaying plane-parallel stratification. These sandstone facies are organized in fining-upward cycles locally limited at the base by discontinuous layers of clast-supported conglomerates. DS2 paleocurrents (203 measurements) in the Serra do Tonã area indicate a consistent southward paleoflow (mean azimuth toward $176^{\circ}$ ).

Fine to coarse-grained sandstones overlie the conglomeratic sandstones of lower DS2, occurring as centimeter to decimeter scale-thick cross strata sets, locally displaying sigmoidal cross stratification (Fig. 6B). These deposits occur in fining upward successions transitioning into coarsening upward successions of shales interbedded with fine to medium sandstones (Fig. 6C), displaying climbing-ripple cross-lamination and trough cross-stratification. Detrital micas and clay occur as drapes in the foresets (Fig. 6D). Some sandstone beds with trough cross-stratification up to $2 \mathrm{~m}$ thick show ripples on foreset toes. Contacts between thicker sandstone beds and mud-dominated facies may exhibit overload features such as flame structures, forming balls and pillows. 

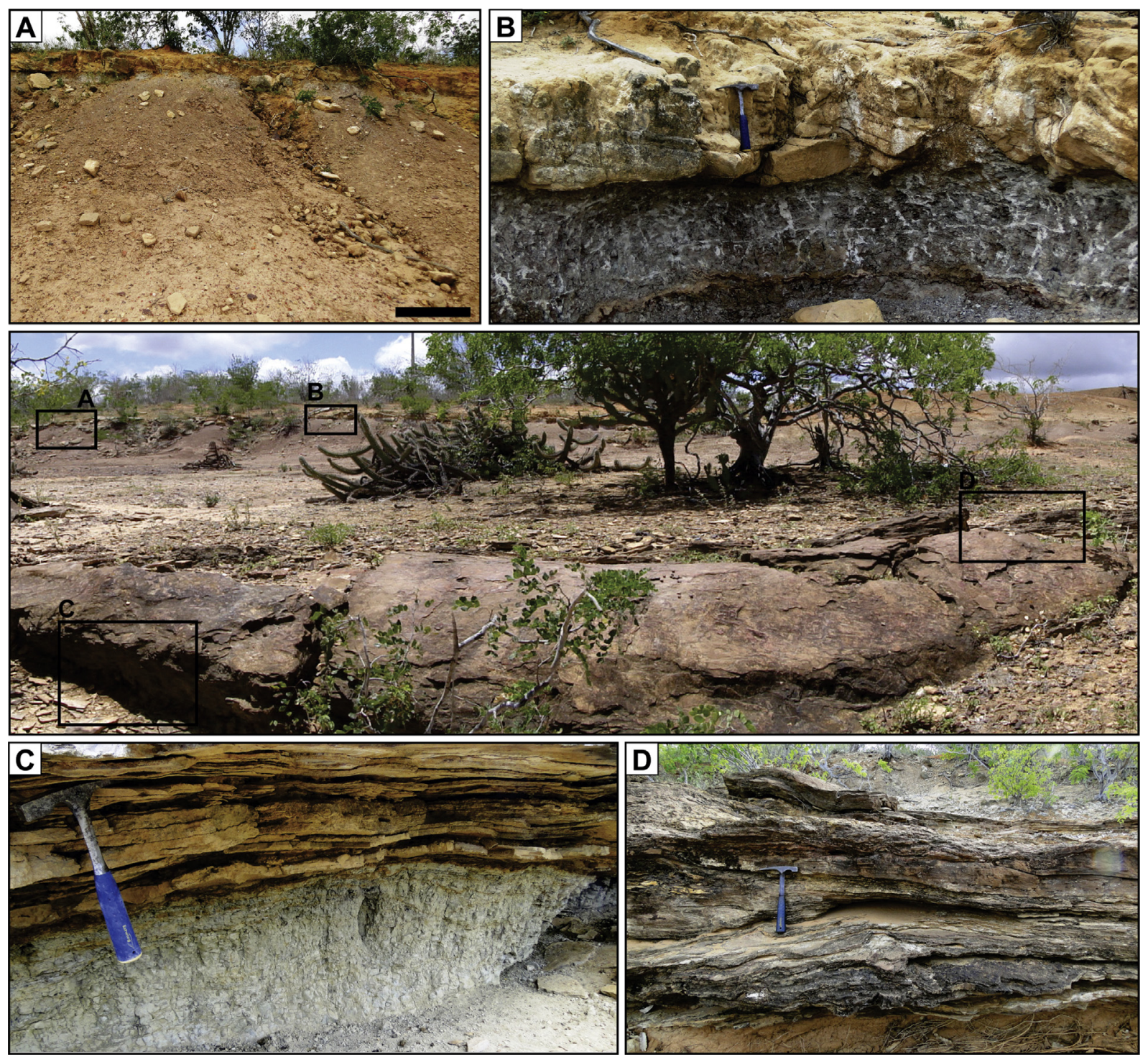

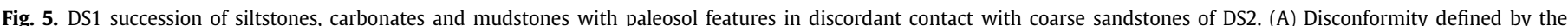

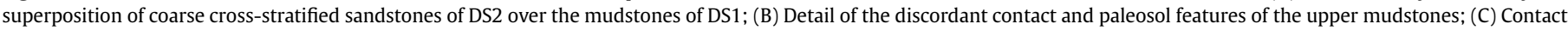
between siltstones and microbial laminites; (D) Laminated mudstone forming dome features. Scale bar corresponds to $1 \mathrm{~m}$ and hammer is $279 \mathrm{~mm}$ long.

An important carbonate section composed of $20 \mathrm{~m}$ thick of planar laminites cover the entire Serra do Tonã plateau and constitutes the top succession of the DS2 (Fig. 7). Dark-gray shales occur interbedded with the carbonates in the lower portion of the carbonate section and may form heterolithic bedding marked by centimeter-scale beds of planar laminites, with flat bases and wavy tops, interbedded with light-colored siltstones. The heterolithic section is covered by an interval of mudstones $(2-4 \mathrm{~m})$, with lamination marked by alternating lenses of light and dark micrite and by the presence of thin, organic matter-rich films. Nodular laminites are present in the upper part of the interval and are associated with grapestones intraclasts and irregular laminae with important organic matter content and sparse quartz, feldspar and mica grains.

\section{Carbonate microfacies}

Based on carbonate microfacies, three deepening-upward cycles $(10-70 \mathrm{~cm})$ were recognized in the carbonate interval of the upper DS1, mainly in Salgado do Melão and São Saité areas (Fig. 8). The first cycle shows undulated and nodular laminites formed by millimetric carbonate laminae $(\sim 0.25 \mathrm{~mm})$, of crumbly texture, composed of micrite and peloids, interspersed with organic clayey films with serrated profiles or irregular, tuber-shaped laminae (Fig. 9A-B). Carbonate laminae are formed by spherules interpreted as coccoid cells with preserved sheaths that are $1-40 \mu \mathrm{m}$ in diameter. The cells are especially evident in the silicified portions of the rock (Fig. 9C). Clay-organic films show irregular, wavy to crenulated shapes and bear pyrite, gypsum and magnesium sulfate crystals (Fig. 9D). Some organic laminae are rich in rounded and elongate intraclasts composed of micrite, disarticulated ostracods and fish's bone fragments. Although disseminated pyrite can be very common in the carbonate deposits, they are concentrated in organic films. Nodules show radial patterns with silica replacement (spherulites) and articulated ostracods with drusiform cement containing coccoid cells and chalcedony inside closed valves. The end of the cycle is marked by the presence of bioclastic wackestones, which are characterized by articulated and disarticulated parautochthonous ostracods floating in micritic matrix. The ostracods may occur as shell fragments clusters, which are dispersed 

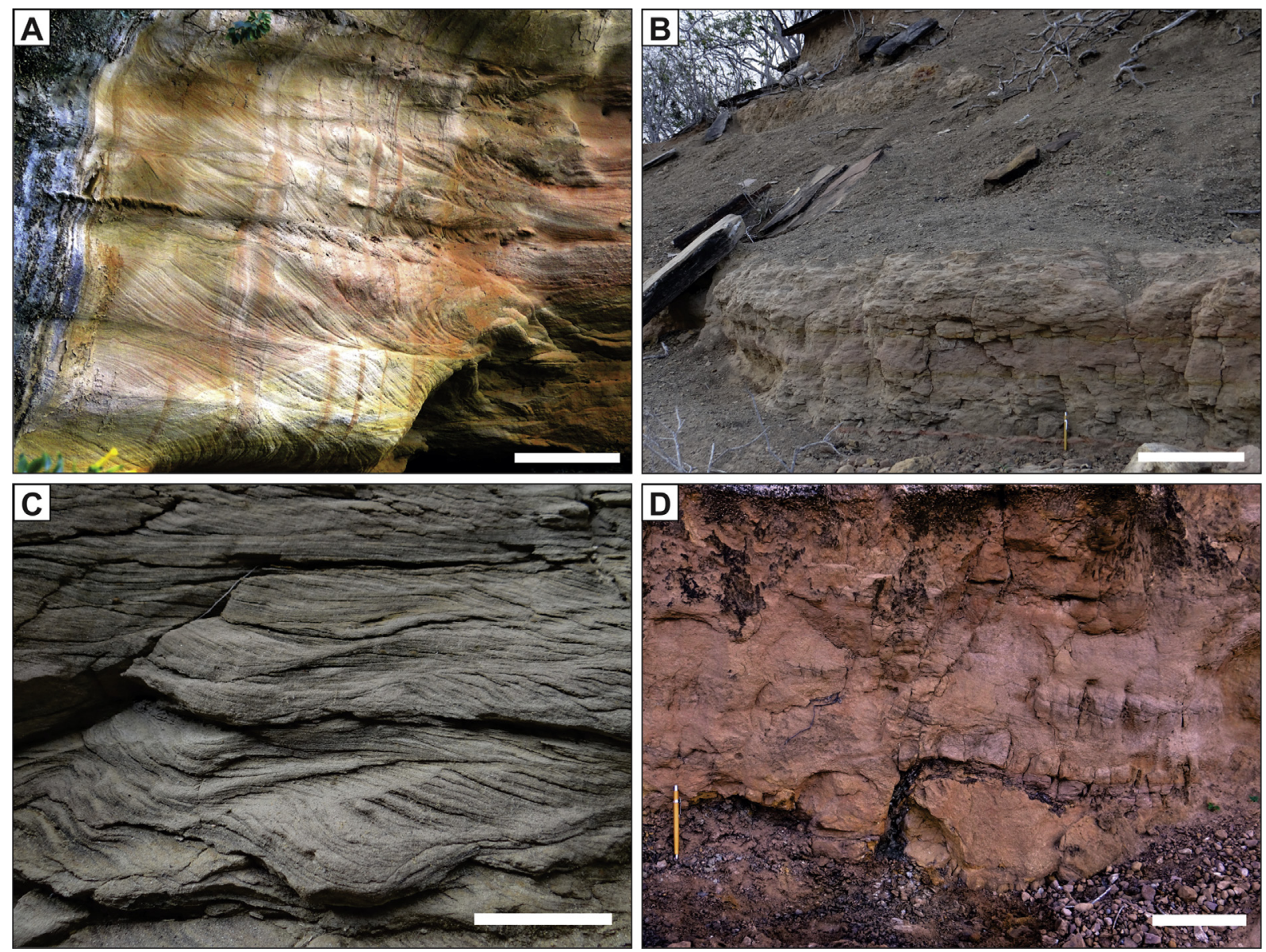

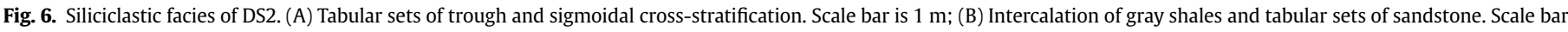
is $30 \mathrm{~cm}$; (C) Climbing ripples with mafic/heavy minerals in the foresets. Scale bar is $5 \mathrm{~cm}$; (D) Sandstone with load structure above shale. Scale bar is $15 \mathrm{~cm}$.

throughout the matrix, or millimeter-thick deposits outlining irregular/wavy lamination. Rhombohedral crystals of dolomite presenting stains of iron oxides and hydroxides are present in large amounts, decreasing toward the top.

Rudstones composed of micrite intraclasts $(0.5-3 \mathrm{~mm}$ thick) sometimes containing coccoid cells, ostracod and fish fragments, or even other intraclasts (grapestones), initiate the second cycle. Laminites with clay-organic levels containing ostracods, rounded intraclasts and oncoids are overlapping. The laminites are followed by ostracodites interspersed with shales, with laminae formed by ostracods typically articulated, aligned and stretched in the bedding planes (Fig. 9E). The third cycle is the thickest and has the least diversity of microfacies. It starts with nodular laminites followed by planar laminites, formed by micrite/microsparite interlaminated with organic matter-rich shale locally containing ostracod shells (Fig. 9F). The regular compositional alternation of laminas in the laminated mudstone microfacies locally produces a rhythmic aspect. Loop bedding features, microfaults and boudins microscopically reproduce the centimetric to decimetric convoluted, recumbent, and kink folds observed on outcrops.

The carbonate section of DS2 is a transgressive-regressive cycle. The transgressive stack pattern starts with thin planar laminites with evidence of subaerial exposure, such as breccia levels and millimeter-scale tepees. Lamination is marked by alternating light and dark laminae with different calcite crystallization stages and local thin clay-organic films. The carbonates are interbedded with dark shales in which plants fragments and ostracods may be found. Undulated laminites characterized by the presence of organic matter films and coccoid cells a few micrometers in diameter and grouped in pockets are also part of the facies association. The deepening of the water table is indicated by the presence of planar laminites that are partly rhythmic. Some laminae show concentration of articulated, disarticulated, and fragmented ostracods, in addition to phosphatic fragments (mainly fish scales and teeth). The shallowing upward pattern is indicated by the reappearance of undulated and nodular laminites, with convex-upward forms forming locally clusters of millimeter to centimeter-scale domes (stromatolites). Lamination becomes serrated or irregular in the presence of interspersed organic matter films and wavy, when spherulites and grapestones are present.

\section{Depositional system tracts}

After a long erosional period during the entire early Aptian, the resumption of subsidence due to the reactivation of faults generated in the rift phase (Figueiredo et al., 2015) allowed the preservation of the late Aptian sedimentation in the Tucano Basin. The lower sandstone-dominated succession with minor conglomerate was thereby generated, and its facies association is typical of deposition in rivers with braided channel patterns, which were associated with alluvial fan deposits right above the erosive paleosurface developed in the early Aptian (Freitas, 2014; Figueiredo et al., 2015; Almeida et al., 2016). The progradational pattern of the fluvial bedforms is typical of the Lowstand System Tract (LST) stratigraphic architecture. 

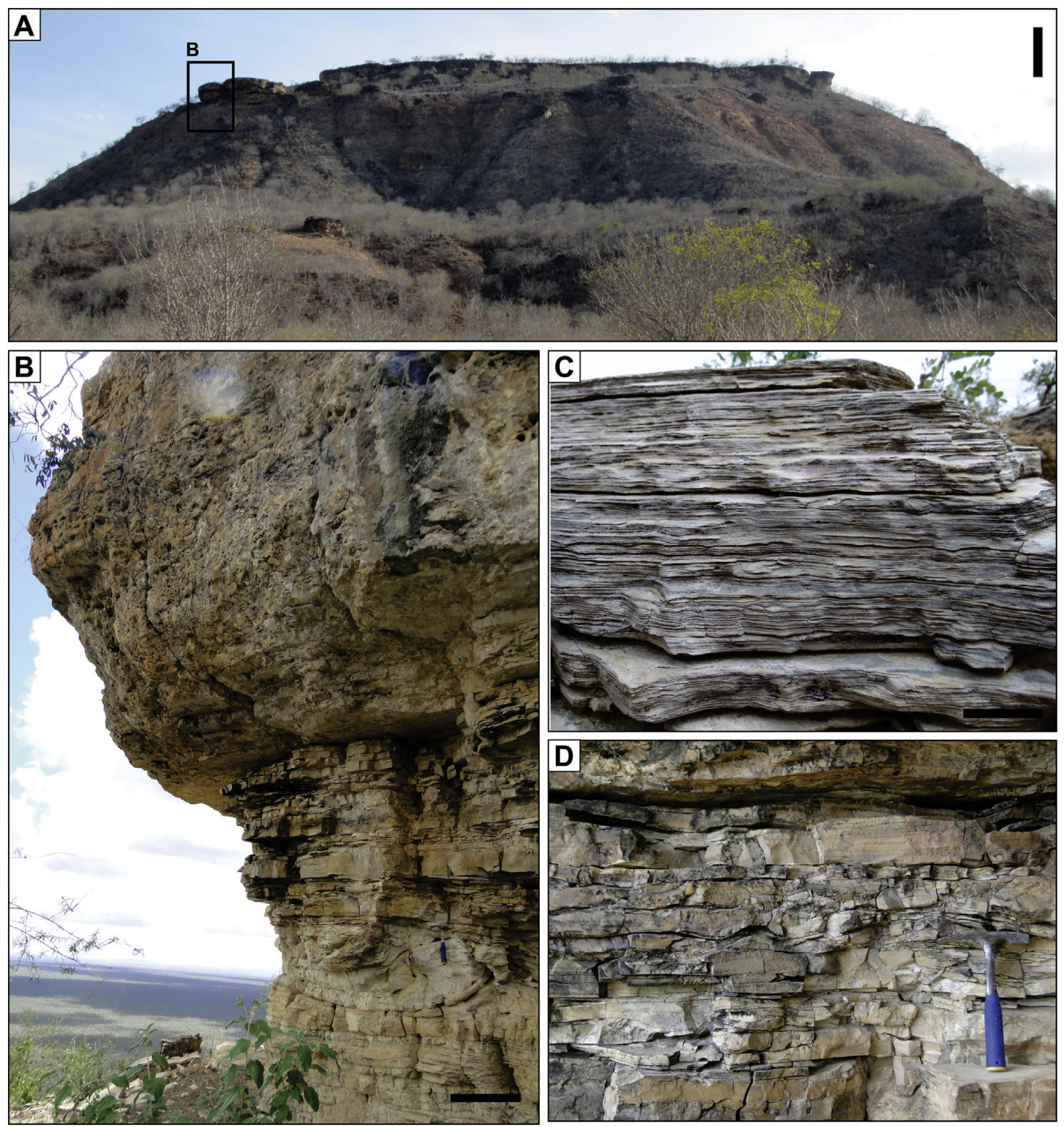

Fig. 7. Carbonate facies of DS2 in the São Saité hill. (A) Overview of the São Saité hill; (B) Outcrop of laminated limestones with deformed beds; (C) Rhythmic; (D) Recrystallized domed stromatolite. Scale bar in A is $20 \mathrm{~m}$, in B is $0.5 \mathrm{~m}$ and in C is $5 \mathrm{~cm}$. The hammer in figure D is $279 \mathrm{~mm}$ long.

The sharp contact between fluvial and lacustrine deposits defines the transgressive surface. The fine grained deposits of this interval are characterized by sandstones with ripples and shales organized in thin thickening upward successions are interpreted as terminal splays of the fluvial system into the lake. The Transgressive System Tract continues with the deposition of carbonates in conditions of progressive lake level rise, with shallow water laminites at the base and deeper water facies at the top. This deepening upward tendency is evidenced by three high-frequency cycles (Figs. 3, 8). The undulated and nodular laminites are interpreted as microbialites deposited as microbial mats (Burne and Moore, 1987) and thus, the product of organomineralization (Perry et al., 2007), with mineral precipitation mediated by the activity of photosynthetic microbial communities and the formation of extracellular polymeric substances (EPS) (Dupraz et al., 2009). Bacteria show variable activity depending on supplies of light and organic matter, tending to decrease in intensity below $20 \mathrm{~cm}$ depth (Jorgensen, 1977). Modern microbial mats are usually restricted to habitats with extreme, stressful conditions, such as high-salinity and high-pH environments, which preclude the existence of predatory organisms (such as gastropods and copepods) or competition for light (Des Marais, 1995). The association of the Marizal Formation microbial mats with calcium sulfate (gypsum), magnesium sulfate (epsomite/kieserite), cracks and tepees suggest that the same occurred in the Tucano Basin during the Aptian. In other words, the carbonate bio-induced sedimentation occurred in shallow, high-salinity waters with frequent subaerial exposure. 


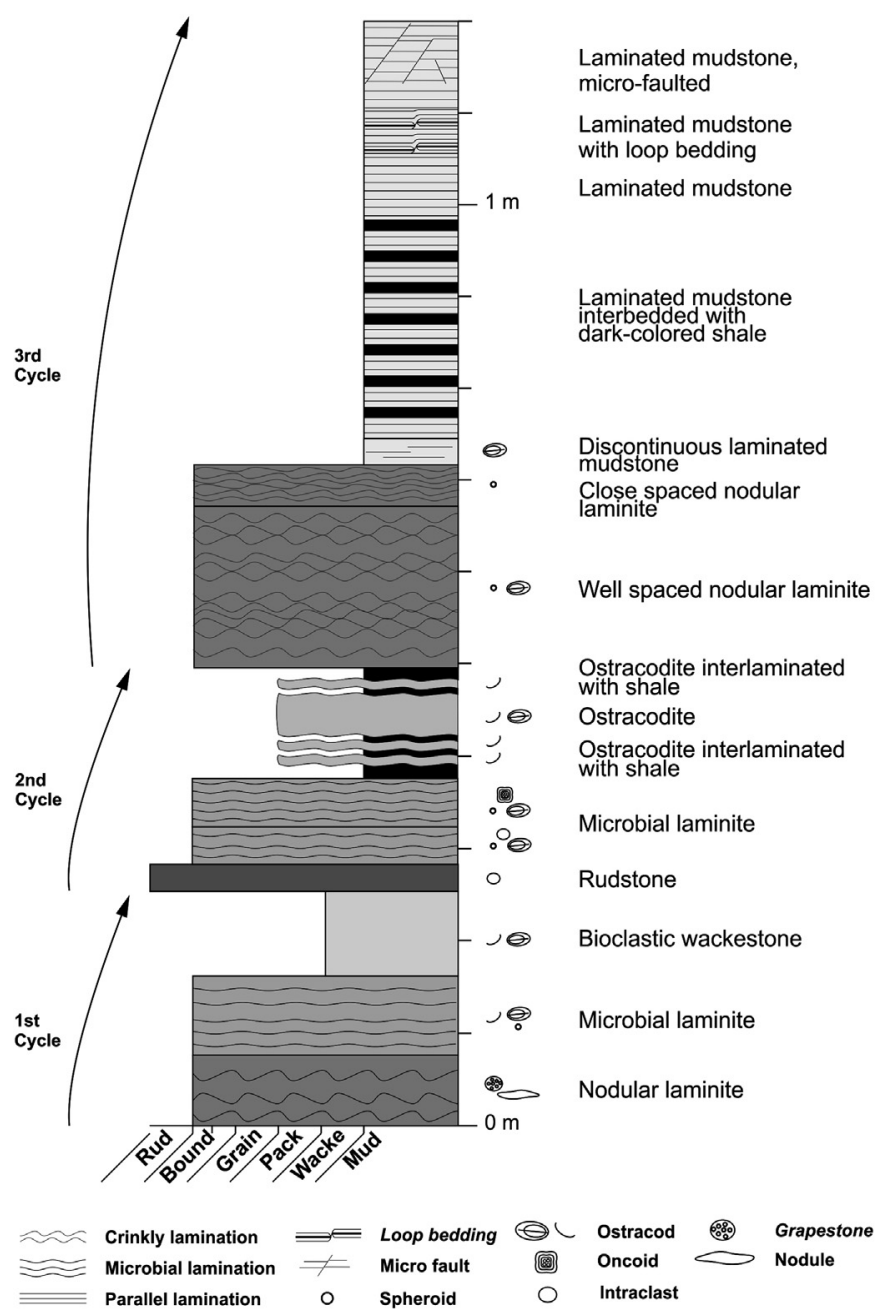

Fig. 8. Schematic vertical profile of the carbonate bed of DS1 detailed with the aid of petrographic descriptions and observations of samples via scanning electron microscopy (SEM). The presence of three drowning cycles is observed, with the superposition of laminites, wackestones and ostracodites by mudstones. Rud = rudstone, Bound $=$ boundstone, Grain $=$ grainstone, Pack $=$ packstone, Wacke $=$ wackestone, Mud $=$ mudstone.

The preservation of ostracodites, the dark color of associated shales and the occurrence of planar laminites also suggest deposition in relatively deeper and anoxic/dysoxic bottom waters. Planar laminites form rhythmites stricto sensu in which the precipitation of carbonates was probably seasonal and affected by varying influxes of terrigenous materials (Gierlowski-Kordesch, 2010). The main factors that favored the preservation of the lamination observed in this microfacies is the substrate stabilization promoted by the bentonic microbial community (Renault and Gierlowski-Kordesch, 2010), and changes in salinity due to the seasonal events of water input and evaporation (Quijada et al., 2013). Despite the evidences of carbonate deposition in conditions of stable substrate, some deformational structures, including loop bedding and slumps associated to the uppermost carbonate bed (Calvo et al., 1988; Rodriguez-Pascua et al., 2000), are suggestive of periods of destabilization due to tectonic activity.

Above the carbonate bed, the meter-thick shale succession suggests a change in the hydrological regime with terrigenous input and settling of mud in the bottom of the lake. The development of a paleosol bed in the last meter of these shales is a good evidence of subaerial exposure and cessation of sedimentation. There is no sedimentological evidence that support the presence of a Maximum Flood Surface (MFS) in the shale succession.

An event of fluvial incision, responsible for the irregular character of the erosional surface resulting in large thickness variations of the carbonate-siliciclastic succession, marks the boundary between the two depositional sequences recognized in the Marizal Formation. The DS2 starts with medium to coarse, locally conglomeratic, fluvial sandstones with trough cross-bedding. In some cases, sandstone bodies show fining-upward cycles. Shales are rare, being remnants of floodplains or bar top deposits often eroded and incorporated into sandstones as intraclasts (Collinson, 1996). The low shale content indicates that the sediments were deposited in braided river channels, although this grain size ratio alone is not enough to speculate about the channel style (e.g., Bridge, 2003; Adams and Bhattacharya, 2005). The relatively coarse grain size and the association with a wide, regional scale, erosional surface, support the interpretation of a Lowstand System Tract (LST) for the lower DS2.

The upper part of the DS2 siliciclastic sequence shows increased mud content toward the top, outlining a transgressive stacking in the TST. Coarsening upward sandstone beds occur interbedded with shales. These sandstones show climbing-ripple cross-lamination in the lower ends of large-scale foresets of trough crossstratifications, with lower angles and gradation to shales, similar to river-mouth bars in interdistributary bays of deltaic systems (Tye and Coleman, 1989). These facies represent the transition to the laminated limestones at the top, which generally have thicknesses of less than $20 \mathrm{~m}$ and were deposited in lake systems with varying salinity, including periods of high salinity (Silveira et al., 2014).

The deposition of laminated limestones preserved on top of Serra do Tonã represents the peak of lacustrine sedimentation recorded in the Tucano Basin after Neocomian times, with the development of a water body probably deeper than that recorded in DS1. Carbonate lacustrine deposition began again in a new TST, with a shallow and fluctuating waterbody. In this system, microbial mats and intraformational breccias, consisting of clasts derived from the reworking of microbial laminites and vegetation fragments, are evidence of shallow waters. These facies are covered by planar laminites recording progressively deeper conditions until the MFS. Nodular laminites and domes at the top of the succession indicate a deceleration of the rising lake level and increasing organic productivity, characterizing a regressive stacking in the HST.

\section{Coeval stratigraphic units and paleogeographical reconstitution}

The fluvial facies of the lower sequence (DS1), which are typical of the lower section of the Marizal Formation, are overlain by a thin section ( $<15 \mathrm{~m}$ thick) of shales interbedded with lacustrine limestones. These deposits are laterally continuous in the entire Tucano Basin along its southern, central and northern segments (Ghignone, 1978), and can be ascribed to the Amargosa Bed (Freitas, 2014). The Amargosa Bed is described in the Central Tucano Basin as a decimeter to meter-scale thick mud-dominated sedimentary unit that comprises heterolithic and sand deposits with wave and current ripples interbedded with shales and rare thin carbonate beds (Freitas, 2014).

The known fossils described for the Marizal Formation are exclusively found in the Amargosa Bed (Freitas, 2014) and include plant remains of angiosperms (Barbosa, 1950); palynomorphs (Viana et al., 1971); dinoflagellates (Regali, 2000); an invertebrate fossil fauna, composed of ostracodes (Ghignone, 1963), bivalves (Barbosa, 1950; Campo and Campos, 1976), gastropods (Silva Santos, 1972; Santos and Brito, 2005), conchostracans (Roxo, 

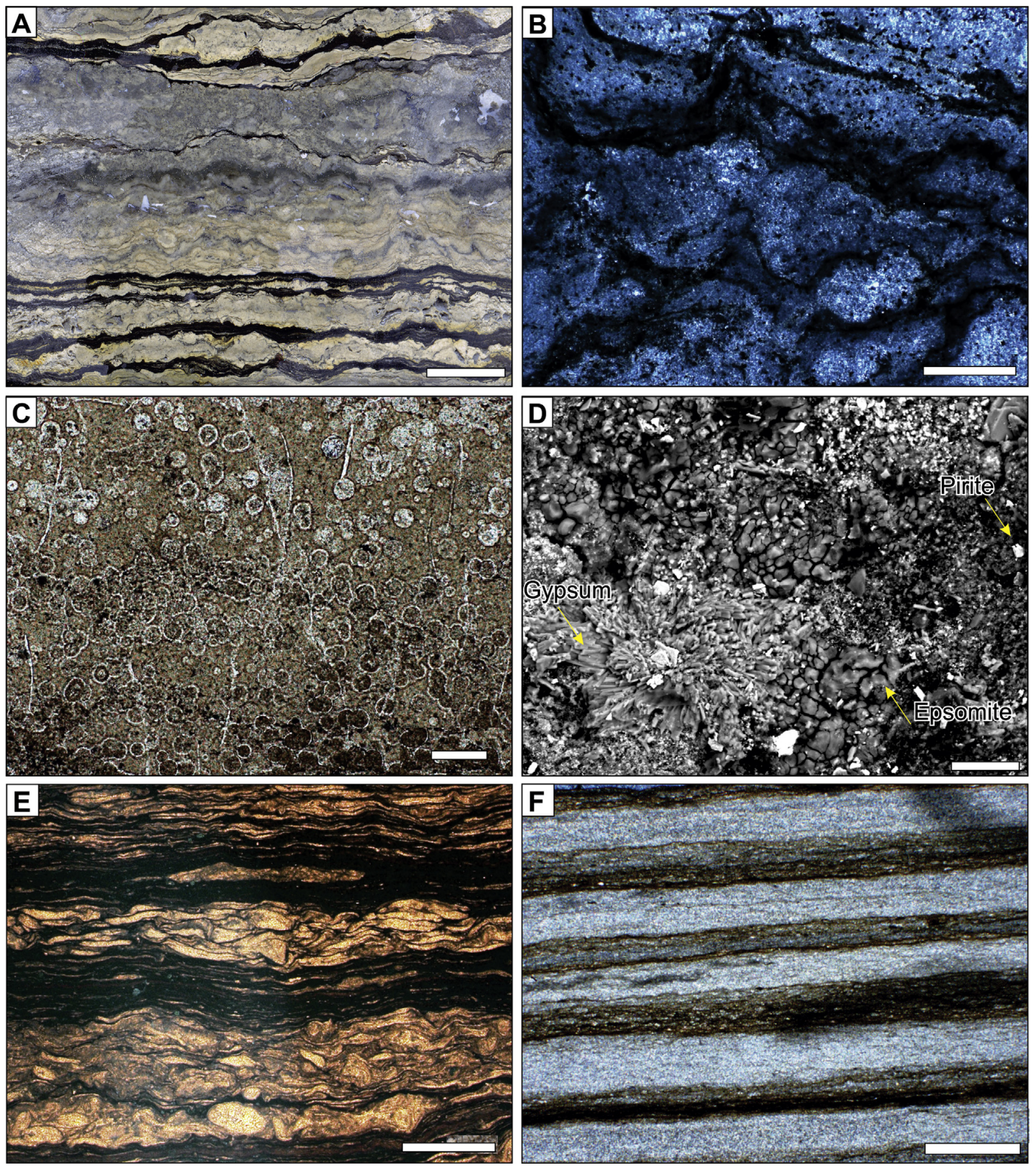

Fig. 9. Photomicrographs of the carbonates of DS1. (A) Laminite sample with irregular lamination and organic matter films. Scale bar is $1 \mathrm{~cm}$; (B) Microscopic detail of the tubershaped laminae with films of organic matter. Scale bar is $1 \mathrm{~mm}$; (C) Spheroids with diameters ranging from 1 to $40 \mu \mathrm{m}$. Scale bar is $50 \mu \mathrm{m}$; (D) Detailed scanning electron microscopy images of organic matter-rich films showing an association between gypsum and epsomite crystals. Scale bar is $40 \mu \mathrm{m}$; (E) Ostracodite interbedded with dark shale. Scale bar is $1 \mathrm{~mm}$; (F) Planar laminite with rhythmic aspect. Scale bar is $1 \mathrm{~mm}$.

1940; Silva Santos, 1972; Campo and Campos, 1976), decapods (Roxo, 1940; Beurlen, 1950; Reis, 2007), and insects (Melo Jr. and Oliveira, 1939). A rich paleoichtiofauna are also found in the Amargosa Bed and include Placidichthys cf bidorsalis, Vinctifer longirostris, Cladocyclus sp., Clupavus brasiliensis (e.g., Silva Santos, 1972, 1973; 1976, 1985; 1990), and four species with advocated Tethyan afinity: Britoichthys marizalensis (Figueiredo, 2004), Placidichthys tucanensis (Brito and Alvarado-Ortega, 2008), Ogunichthys triangularis (Alvarado-Ortega and Brito, 2010), and Nanaichthys longipinnus (Amaral and Brito, 2012).
The Aptian sedimentary record of the Tucano Basin is similar to that of the Araripe Basin (Assine, 2007), located to the north in the Brazilian northeastern hinterland (Figs. 10, 11). Fluvial sandstones predominate in the lower part of the sequence in the Araripe Basin (Assine, 1992; Chagas et al., 2007; Assine et al., 2014; Scherer et al., 2015), where they are also covered by a thin and laterally continuous mud-dominate succession with interbedded limestones and black organic matter-rich shales (Spigolon et al., 2015). This carbonate-shale interval in the Barbalha Formation, called Batateira Beds, is considered a regional stratigraphic landmark in the Araripe 


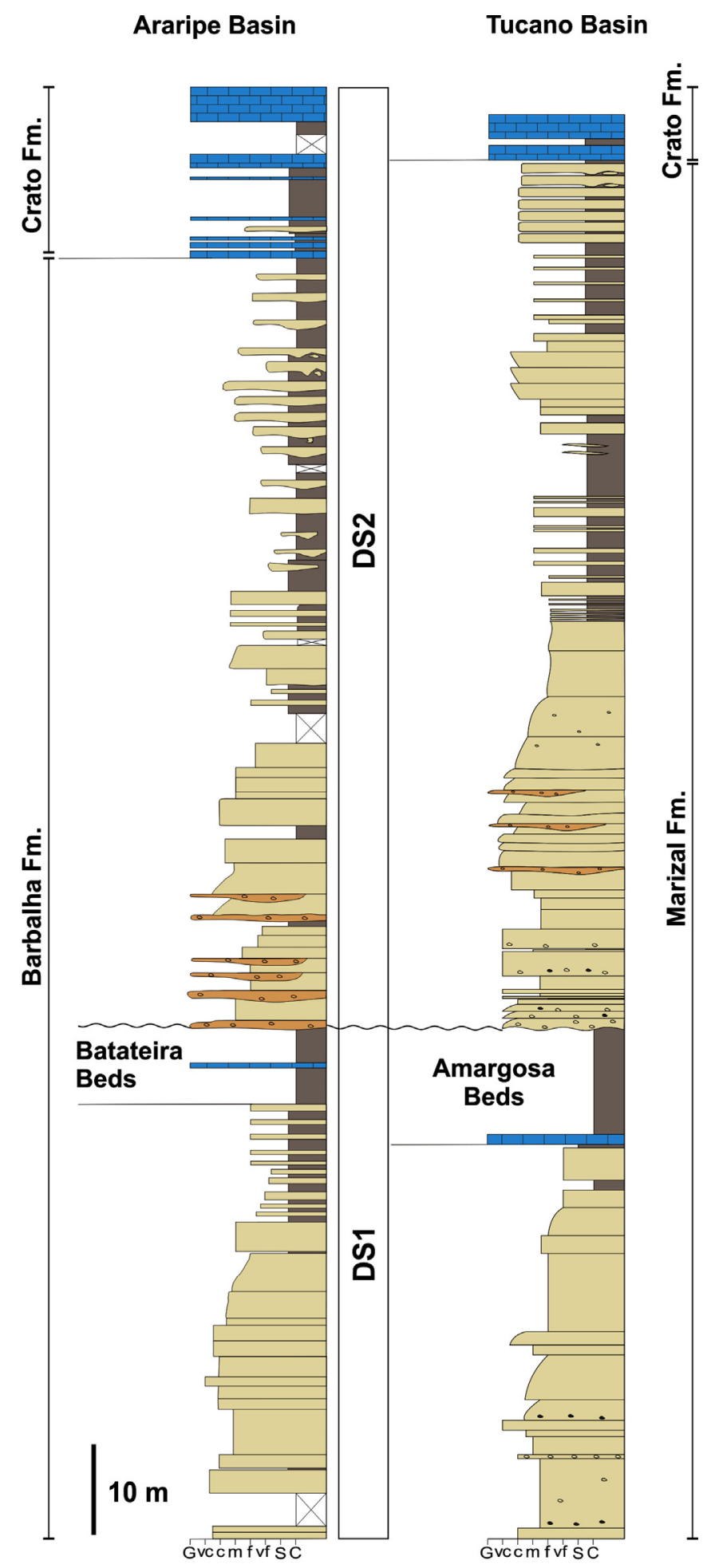

Limestone $0^{\circ}$ Conglomerate shales and, a noteworthy $1 \mathrm{~m}$-thick carbonate layer in its middle portion, composed of millimeter-scale intercalation of dark-colored organic laminae with light-colored ostracodes laminae (Dias-Brito et al., 2015).

As described above, the carbonate bed of DS1 is composed of a meter-scale interval of shales with an approximately 1-meter-thick carbonate bed characterized by microbial laminites, ostracodites and planar laminites. This mixed siliciclastic-carbonate interval is continuous in the entire Tucano Basin. The P-270 palynozone, ascribed to the Amargosa Bed of the Marizal Formation (Regali, 2000), also occur in the Batateira Beds of the Araripe Basin, and in the Trairi (Ceará Basin) and Ponta do Tubarão (Potiguar Basin) beds (Hashimoto et al., 1987). These evidences are strong arguments for the correlation of these important stratigraphic markers.

Paleocurrents obtained from the DS1 fluvial sandstones show a bimodal pattern, with a main east-southeast mode and secondary south-southwest mode, resulting in mean direction toward $105^{\circ}$. These data indicate source areas to the north and west, upstream of the river systems that gave rise to the sandstone sequence of the lower Marizal Formation. This sequence is best exposed in the Central Tucano Basin, south of Serra do Tonã, where the entire sand-dominated succession crops out, including the basal angular unconformity on the Barremian fluvial deposits of the São Sebastião Formation (Figueiredo et al., 2015). In this area, the paleoflow direction is toward $186^{\circ}$, which also indicates a northward source area, but with a unimodal pattern and low angular dispersion. This paleocurrent direction is parallel to the strike of the boundary faults of the Tucano Basin rift, suggesting tectonic conditioning of the sequence by the structures inherited from the rift phase and clearly showing that the predominant drainage was axial south (Fig. 12).

A disconformity at the top of the shale succession (Amargosa Bed) marks the boundary between the two Aptian depositional sequences in the Tucano Basin. The stacking of the DS2 is also retrogradational, with fluvio-deltaic sedimentation, interpreted for the upper Marizal Formation in Serra do Tonã, transitioning to carbonate lacustrine deposition in the upmost Cretaceous succession in the Tucano Basin. Braun (1966) mapped the limestones at the top of Serra do Tonã as Crato Formation, and this criterion was adopted in later works (e.g., Bueno, 1996; Silveira et al., 2014) based on its similarity with the Araripe Basin limestones. In this basin, the sandstones of the Barbalha Formation are covered by the lacustrine laminated limestones of the Crato Formation (Assine, 2007; Chagas et al., 2007; Scherer et al., 2015).

The DS2 also crops out in the Jatobá Basin and is preserved in two inselbergs called Serra Negra and Serra do Periquito (Fig. 1). Planar laminites cropping out in Serra Negra show facies arrangement very similar to those at the top of the Aptian sequences in the Tucano and Araripe basins (Neumann et al., 2010; Neumann and Rocha, 2014), leading Braun (1966) to name them as Crato Formation too. Fluvial sandstones, with similar facies to those of the Tucano Basin, are poorly exposed below the laminated limestones. Fluvial paleocurrents indicate a paleoflow to a mean direction toward $219^{\circ}$. The southwest paleoflow is approximately parallel to the master fault in the north edge of the Jatobá Rift Basin, which suggests axial drainage and syn-depositional tectonism for this sequence. Although this hypothesis requires additional data to be confirmed, the paleoflow data obtained in the Jatobá Basin is coherent with those measured in sandstones of DS2 in Serra do Tonã, which indicates paleoflow to south with mean azimuth of $176^{\circ}$ (Fig. 12).

In the Araripe Basin, the Crato Formation can reach $60 \mathrm{~m}$ in thickness and is formed by several lacustrine limestone beds, with evidences of microbial influence in its deposition (Catto et al., 2016), interbedded with equally thick successions of siliciclastic
Basin (Hashimoto et al., 1987; Assine, 2007) and is positioned in the P-270 palynozone of Aptian age (Lima and Perinotto, 1984; Hashimoto et al., 1987). The Batateira Bed is a $10 \mathrm{~m}$-thick kilometer-long laterally continuous bed characterized by dark

Fig. 10. Correlation of the vertical profile of the Batateira River, Araripe Basin (Assine et al., 2014) and the composite profile of Salgado do Melão and borelog 2-TN-ST-BA, Tucano Basin. 


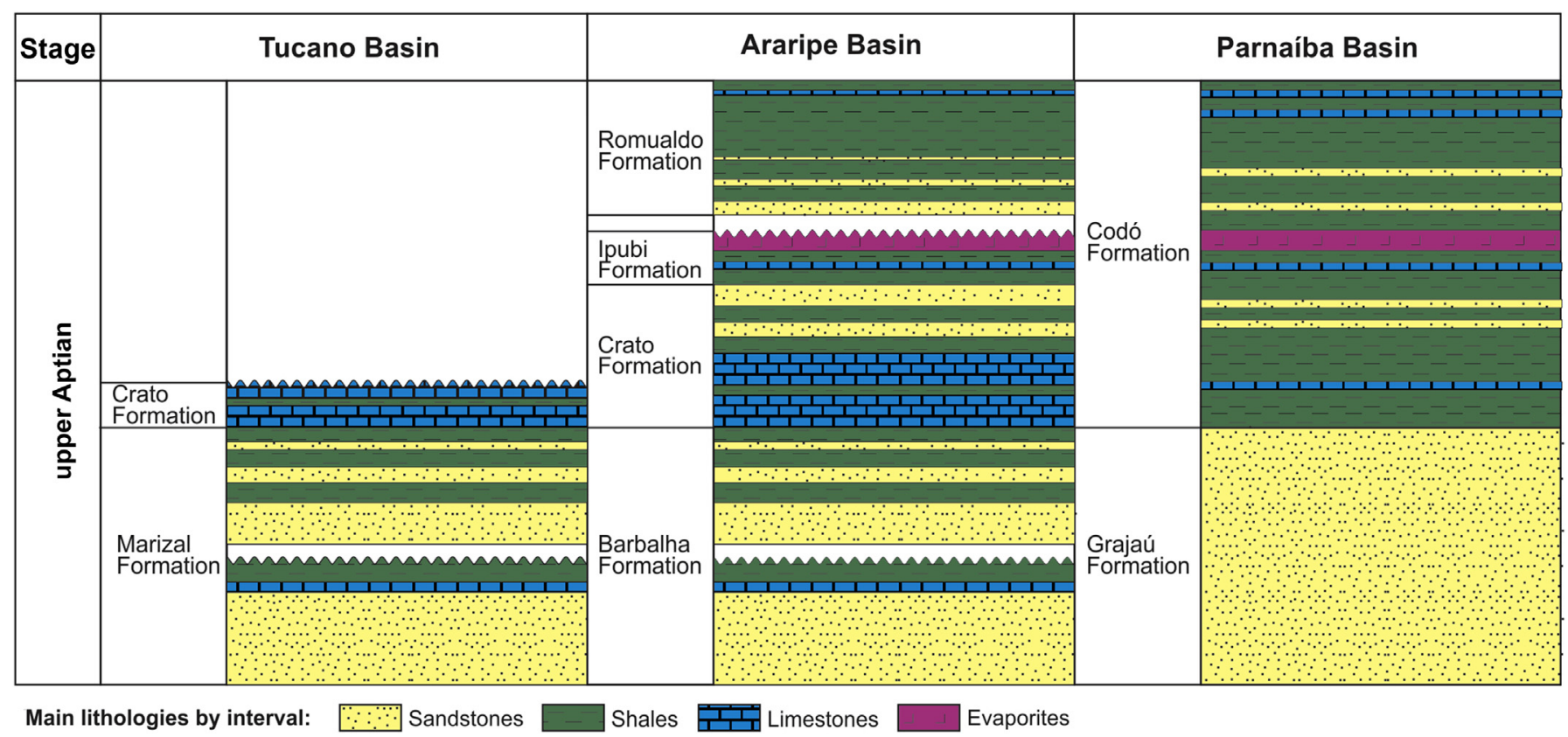

Fig. 11. Correlation of Aptian lithostratigraphic units of the Tucano, Araripe and Parnaíba basins.

facies (Silva and Neumann, 2003). The rich fossil assemblage of the Crato Formation was originally interpreted as having lived in a nonmarine setting (Mabesoone and Tinoco, 1973), probably in a saline lacustrine environment (Assine, 1992, 2007; Neumann, 1999). More recently, several authors (e.g. Mohr and Eklund, 2003; Makarkin and Menon, 2005; Martill et al., 2007b; Do Carmo et al., 2008; Baez et al., 2009) suggested that the carbonates were deposited in a hypersaline lagoon system with restricted connection to an epeiric sea in the southeast (Assine et al., 2016). However, the Aptian stratigraphic record is incomplete in the Tucano Basin because the carbonate section is only a few meters thick. Still, its presence indicates that the original extent of late Aptian carbonate deposits was much larger than is currently preserved in the Brazilian northeastern hinterland (Braun, 1966; Assine, 1990, 1994).

An intriguing question remains about the origin of calcium carbonate in the upper Aptian carbonates of Tucano Basin. The proximity with seawaters and a possible limited marine water input on the freshwater body can explain the saline periods and the source to the calcium carbonate, but further additional data is needed to better explain this anomalous layer in the siliciclastic succession of the lower sequence. In the case of Crato Formation limestones, isotope data indicate that they were deposited in an exclusively freshwater body with periods of saline waters (Silveira et al., 2014) originated by bicarbonate massive input from the adjacent Neoproteroroic basement (Rolim, 1984).

The lack of complete upper Aptian stratigraphic records in the Tucano Basin is evident due the absence of the correspondent gypsum layers of the Ipubi Formation, that covers the Crato Formation limestones in the Araripe Basin (Beurlen, 1971). The evaporites characterize the transitional stage between the rift and drift sequences and are present in most Brazilian marginal basins (Chang et al., 1988, 1992). Gypsum layers occur even west of the Parnaíba Basin, where the evaporitic-carbonate section of the Codó Formation overlays the fluvio-deltaic facies of the Grajaú Formation (Rossetti et al., 2004; Paz et al., 2005; Paz and Rossetti, 2006; Bahniuk et al., 2015).

The upper Aptian marine sequence of the Araripe Basin, enclosed in the Romualdo Formation, records the late Aptian marine transgression in the Brazilian northeastern hinterland (Assine, 2007; Assine et al., 2014), and does not occur in the Tucano Basin. Indeed, beyond the Araripe Basin, relicts are only preserved in the two inselbergs of the Jatobá Basin. However, this section is poorly exposed, hampering measurements of stratigraphic sections.

Before the Romualdo transgression, a precedent late Aptian marine ingression is envisaged for the fossil record of the Amargosa Bed of the Marizal Formation. Shales, siltstones and minor carbonate deposits, recently defined as the Amargosa Bed (Freitas, 2014), provided fossil fish, as reported by Silva Santos (1972), that has been ascribed to a marine Tethyan realm (Brito and AlvaradoOrtega, 2008; Alvarado-Ortega and Brito, 2010; Amaral and Brito, 2012). If these deposits were formed in an epicontinental sea, the ingression would not have reached the North Tucano Basin because no marine evidence was found in the carbonate-shale interval of the upper DS1.

Fluvial paleocurrents obtained from the Marizal Formation in the North Tucano, in the Central Tucano, and in the Jatobá basins, as well as from the coeval deposits of the Barbalha Formation in the Araripe Basin, indicate a paleodrainage formed by rivers that flowed from north to south, from the Araripe Basin to the Recôncavo Basin through the Tucano Basin (Fig. 12). The paleocurrent data from Tucano and Jatobá basins are coherent with those from Araripe basin that also indicates a southward paleoflow (Assine, 1994). In this paleogeographic scenario, marine ingressions must have occurred from south to north- that is, upstream from the Recôncavo - up the river valleys until reaching the Araripe Basin The strong evidence of Tethyan fossils rather than Austral assemblages during the Aptian of the Sergipe, Central and South Tucano basins are suggestive of a surface-water connection between Central and South Atlantic oceans through an incipient Equatorial Atlantic gateway (Bengtson et al., 2007). These results conflicts with the paleogeographic continental interpretation that a seaway derived from north occupied the northeast province of Brazil as proposed by Arai (2014) and support the reconstruction recently presented by Assine et al. (2016). 


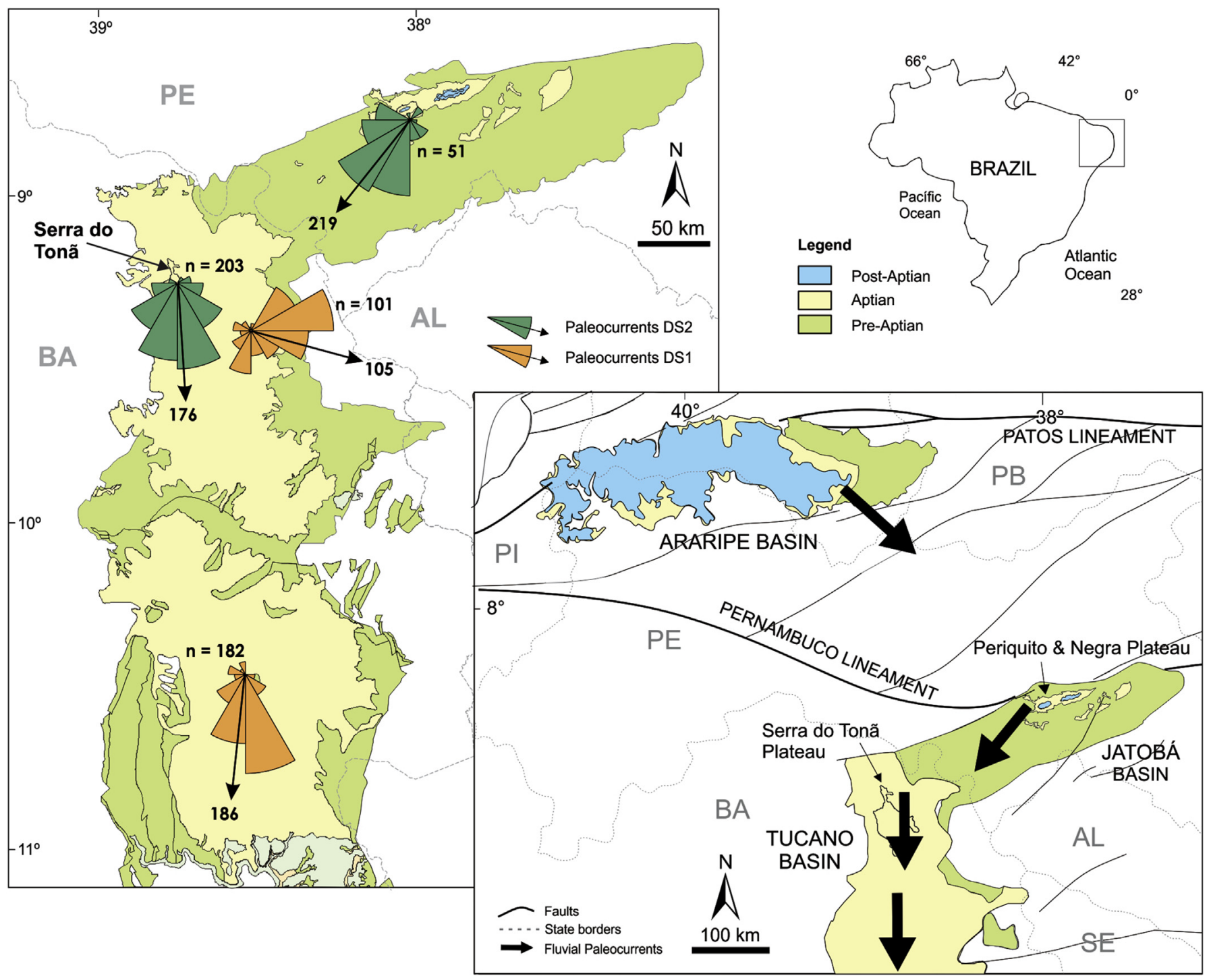

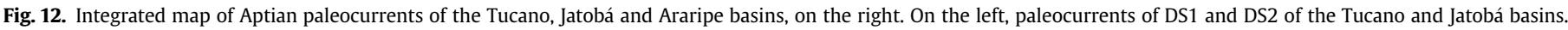

The relict preservation of the upper Aptian section in the Brazilian northeastern hinterland, especially the lacustrine laminated limestones, transitional evaporites and marine shales, was the result of regional uplift events, with denudation and removal of much of the Cretaceous sedimentary record in the area from the Campanian to the Miocene (Magnavita et al., 1994; Peulvast et al., 2008; Japsen et al., 2012). The Araripe Basin is the main record of these deposits, but the occurrences of Serra do Tonã in the Tucano Basin and Serra Negra in the Jatobá Basin are critical to reconstruct the Cretaceous geological history of the Gondwana break-up and South Atlantic opening recorded in northeastern Brazil.

\section{Conclusion}

Two mixed carbonate-siliciclastic sequences, separated by regional disconformities, were identified in the upper Aptian record of the Tucano Basin. The sequences are predominantly transgressive, with fluvial facies at the bottom and lacustrine deposits at the top. The lacustrine stratigraphic records show cyclicity, probably resulting from fluctuations in salinity and water depth, with microbialite deposition in the shallow regions and mudstones occurring in deeper waters.
The upper Aptian depositional sequences are correlated with those of the Aptian Santana Group of the Araripe Basin. The fluvial facies of the Marizal (Tucano) and Barbalha (Araripe) formations show similar patterns of retrogradational stacking, culminating in lake systems. The shale interval (Amargosa Bed), which includes limestone beds comprising high-frequency deepening cycles, is an important stratigraphic landmark in the Tucano Basin, similar and correlated with the Batateira Beds in the Araripe Basin. The occurrence of this older lake system in the North Tucano Basin at the end of the first sedimentary cycle resulted from a rising regional base level and drowning of river plains. This event was related to the transgression that caused the deposition of facies believed to be marine further south, in the Central Tucano Basin, where paleoichthyofauna of Tethyan affinity has been interpreted.

The second sedimentary cycle ends with the generation of predominantly carbonate lake systems, which are litho- and chrono-correlated with those of the Crato Formation of the Araripe Basin. The laminated limestones of this formation, which are also present in the Jatobá Basin, represent a relict record of an originally more extensive coverage, eroded due to epeirogenic uplift of the Brazilian northeastern hinterland from the Campanian to the Miocene. 
Paleocurrents deduced from the dip direction of fluvial crossstrata indicate that the Tucano Basin was part of a continentalscale paleodrainage flowing southwards, in north-south valleys probably conditioned by subsidence associated with the reactivation of rift phase faults in the Tucano Basin. These valleys formed natural paths for the upper Aptian marine ingression, which reached the Araripe Basin to the north, giving rise to the marine shales of the Romualdo Formation. The stratigraphic record of the Tucano Basin is key issue to elucidate the depositional history of the late Aptian in the Brazilian northeast. Indeed, this record has important paleogeographical implications regarding the continental paleodrainage and the paths through which the sea advanced inland at a time when the South Atlantic Ocean was connected to waters from the Tethys in a restricted Equatorial Atlantic gateway.

\section{Acknowledgments}

The authors are deeply indebted to the reviewers, specially to Nilo C. Azambuja Filho, for their extensive and very constructive comments, which greatly helped to improve an earlier version of the manuscript. The authors thank Petrobras (process $\mathrm{n}^{\circ}$ 0050.0023165.06.4 - SAP $n^{\circ}$ 46.00321584), the São Paulo Research Foundation (FAPESP) (research grants 2004/15786-0 and 2014/ 16739-8, scholarship 2010/51559-0) and CNPq (proc. 476727/20049, 302905/2015-4) for supporting this study; the Center for Geosciences Applied to Petroleum Geology - UNESPetro, IGCE/Unesp/ Rio Claro, for supporting the development of the study, as well as the University of São Paulo for institutional support; the Training of Human Resources in Petroleum Geology Program - UNESP - PRH 05 for granting the masters scholarship (FGV); CNPq for research grants to some of the authors (MLA, JAJP, RPA and VHN); and Bruno Cesar Araújo for collaboration during the fieldworks.

\section{References}

Adams, M.M., Bhattacharya, J.P., 2005. No change in fluvial style across a sequence boundary, Cretaceous Blackhawk and Castlegate formations of Central Utah, U.S.A. Journal of Sedimentary Research 75, 1038-1051.

Almeida, R.P., Freitas, B.T., Turra, B.B., Figueiredo, F.T., Marconato, A., Janikian, L. 2016. Reconstructing fluvial bar surfaces from compound cross-strata and the interpretation of bar accretion direction in large river deposits. Sedimentology 63, 609-628.

Almeida-Filho, R., Miranda, F.P., Yamakawa, T., Bueno, G.V., Moreira, F.R., Camargo, E.G., Bentz, C.M., 2002. Data integration for a geologic model of hydrocarbon microseepage areas in the Tonã Plateau region, North Tucano basin, Brazil. Canadian Journal of Remote Sensing 28, 96-107.

Alvarado-Ortega, J., Brito, P.M., 2010. A new ichthyodectiform (actinopterygii, teleostei) from the Lower Cretaceous Marizal Formation, North-East Brazil. Palaeontology 53, 297-306.

Amaral, C.R.L., Brito, P.M., 2012. A New Chanidae (Ostariophysii: Gonorynchiformes) from the Cretaceous of Brazil with Affinities to Laurasian Gonorynchiforms from Spain. PLoS One 7, e37247.

Arai, M., 2014. Aptian/Albian (Early Cretaceous) paleogeography of the South Atlantic: a paleontological perspective. Brazilian Journal of Geology 44, 339-350.

Assine, M.L., 1990. Sedimentação e tectônica da Bacia do Araripe, Nordeste do Brasil. Instituto de Geociências e Ciências Exatas, Unesp, Rio Claro. Dissertação de Mestrado, 124 pp..

Assine, M.L., 1992. Análise estratigráfica da Bacia do Araripe, Nordeste do Brasil. Revista Brasileira de Geociências 22, 289-300.

Assine, M.L., 1994. Paleocorrentes e Paleogeografia na Bacia do Araripe, Nordeste do Brasil. Revista Brasileira de Geociências 24, 223-232.

Assine, M.L., 2007. Bacia do Araripe. Boletim de Geociências da Petrobras 15, $371-389$.

Assine, M.L., Perinotto, J.A.J., Custódio, M.A., Neumann, V.H., Varejão, F.G., Mescolotti, P.C., 2014. Depositional sequences of the Alagoas Stage, Araripe Basin, Northeastern Brazil. Boletim de Geociências da Petrobras.

Assine, M.L., Quaglio, F., Warren, L.V., Simões, M.G., 2016. Comments on paper by M. Arai "Aptian/Albian (Early Cretaceous) paleogeography of the South Atlantic: a paleontological perspective". Brazilian Journal of Geology 46, 3-7.

Baez, A.M., Moura, G.J.B., Gómez, R.O., 2009. Anurans from the Lower Crato Formation of northeastern Brazil: implications for the early divergence of neobatrachians. Cretaceous Research 30, 829-846.
Bahniuk, A.M., Anjos, S., França, A.B., Matsuda, N., Eiler, J., McKenzie, J.A., Vasconcelos, C., 2015. Development of microbial carbonates in the Lower Cretaceous Codó Formation (north-east Brazil): implications for interpretation of microbialite facies associations and palaeoenvironmental conditions. Sedimentology 62, 155-181.

Barbosa, A., 1950. Nota sobre plantas fósseis da Formação Cícero Dantas do Cretáceo da Bahia. Anais da Academia Brasileira de Ciências 1, 25-28.

Bengtson, P., Koutsoukos, E.A.M., Kakakabadzw, M.V., Zucon, M.H., 2007. Ammonite and foraminiferal biogeography and the opening of the Equatorial Atlantic Gateway. 1st International Palaeobiogeography Symposium. Paris, Abstracts, 12.

Beurlen, K., 1950. Alguns restos de crustáceos decápodos d'água doce fósseis no Brasil. Anais da Academia Brasileira de Ciências 4, 453-459.

Beurlen, K., 1971. As condições ecológicas e faciológicas da Formação Santana na Chapada do Araripe (Nordeste do Brasil). Anais da Academia Brasileira de Ciências 43, 411-415.

Braun, O.P.G., 1966. Estratigrafia dos sedimentos da parte interior da Região Nordeste do Brasil (Bacias de Tucano-Jatobá, Mirandiba e Araripe). Boletim DNPM/ DGM 236, 1-75.

Bridge, J.S., 2003. Rivers and Floodplains: Forms, Processes, and Sedimentary Record. Wiley-Blackwell, Oxford, 491 pp.

Brito, P.M., Alvarado-Ortega, J., 2008. A new species of Placidichthys (Halecomorphi: Ionoscopiformes) from the Lower Cretaceous Marizal Formation, northeastern Brazil, with a review of the biogeographical distribution of the Ophiopsidae. In: Cavin, L., Longbottom, A., Richter, M. (Eds.), Fishes and the Break-up of Pangaea, Geological Society of London, Special Publications 295, pp. 145-154.

Bueno, G.V., 1996. Serra do Tonã: um elo estratigráfico entre as bacias do Tucano Norte (BA) e Araripe (CE), Nordeste do Brasil. 4 Simpósio sobre o Cretáceo do Brasil. UNESP/IGCE, Rio Claro, pp. 143-146.

Burne, R.V., Moore, L.S., 1987. Microbialites: organosedimentary deposits of benthic microbial communities. Palaios 2, 241-254.

Calvo, J.P., Rodríguez-Pacua, M., Martin-Velázquez, S., Jiménez, S., Vicente, G.D., 1998. Microdeformation of lacustrine laminite sequences from Late Micone formations of SE Spain: an interpretation of loop bedding. Sedimentology 45, 279-292.

Campo, D.R.B., Campos, D.A., 1976. Localidades fossilíferas da folha Aracajú - SC. 24. In: Bruni, M.A.L., Schobbenhaus, C. (Eds.), Carta geologica do Brasil ao Milionésimo: Folha Aracajú (SC.24). DNPM, Brasília, pp. 167-214.

Catto, B., Jahnert, R.J., Warren, L.V., Varejão, F.G., Assine, M.L., 2016. The microbial nature of laminated limestones: lessons from the Upper Aptian, Araripe Basin, Brazil. Sedimentary Geology. http://dx.doi.org/10.1016/j.sedgeo.2016.05.007.

Chaboureau, A.-C., Guillocheau, F., Robin, C., Rohais, S., Moulin, M., Aslanian, D., 2013. Paleogeographic evolution of the central segment of the South Atlantic during Early Cretaceous times: paleotopographic and geodynamic implications. Tectonophysics 604, 191-223.

Chagas, D.B., Assine, M.L., Freitas, F.I., 2007. Facies sedimentares e ambientes deposicionais da Formação Barbalha no Vale do Cariri, Bacia do Araripe. Nordeste do Brasil Geociencias 26, 313-322.

Chang, H.K., Kowsmann, R.O., Figueiredo, A.M.F., 1988. New concepts on the development of east Brazilian marginal basins. Episodes 11, 194-202.

Chang, H.K., Kowsmann, R.O., Figueiredo, A.M.F., Bender, A.A., 1992. Tectonics and stratigraphy of the East Brazil Rift system: an overview. Tectonophysics 213, 97-138.

Collinson, J.D., 1996. Alluvial sediments. In: Reading, H.G. (Ed.), Sedimentary Environments: Processes, Facies and Stratigraphy. Blackwell Science, London, pp. 37-82.

Demicco, R.V., Hardie, L.A., 1994. Sedimentary Structures and Early Diagenetic Features of Shallow Marine Carbonate Deposits. SEPM.

Des Marais, D., 1995. The biogeochemistry of hypersaline microbial mats. In: Jones, J.G. (Ed.), Advances in Microbial Ecology. Springer, US, pp. 251-274.

Dias-Brito, D., Tibana, P., Assine, M., Rossetti, D., 2015. Laminitos lacustres organocalcários neoaptiano ricos em ostracodes no Nordeste do Brasil: bacias do Araripe, Potiguar e Parnaíba, Aptiano superior (Alagoas superior). In: DiasBrito, D., Tibana, P. (Eds.), Calcários do Cretáceo do Brasil: um Atlas. UNESP/ UNESPetro, Rio Claro, pp. 49-119.

Do Carmo, D.A., Whatley, R., Neto, J.V.Q., Coimbra, J.C., 2008. On the validity of two lower Cretaceous non-marine ostracode genera: biostratigraphic and paleogeographic implications. Journal of Paleontology 82, 790-799.

Dunham, R.J., 1962. Classification of carbonate rocks according to depositional textures. In: Ham, W.E. (Ed.), Classification of Carbonate Rocks AAPG, pp. $108-121$.

Dupraz, C., Reid, R.P., Braissant, O., Decho, A.W., Norman, R.Sf, Visscher, P.T., 2009. Processes of carbonate precipitation in modern microbial mats. Earth-Science Reviews 96, 141-162.

Figueiredo, F.J., 2004. A new Euteleostean fish from the Lower Cretaceous. Arquivos do Museu Nacional do Rio de Janeiro 62, 293-307.

Figueiredo, F.T., Almeida, R.P., Freitas, B.T., Marconato, A., Carrera, S.C., Turra, B.B., 2015. Tectonic activation, source area stratigraphy and provenance changes in a rift basin: the Early Cretaceous Tucano Basin (NE-Brazil). Basin Research $1-13$.

Freitas, B.T., 2014. A Formação Marizal (Aptiano) na Bacia do Tucano (BA): contribuição à análise da arquitetura de depósitos fluviais e implicações paleobiogeográficas, Instituto de Geociências, Universidade de São Paulo, São Paulo. Tese de doutorado, 175 pp..

Ghignone, J.I., 1963. Geologia do flanco oriental da Bacia de Tucano Norte do Vaza dos Barris ao São Francisco. Depex RPBa, Rpt 688. 
Ghignone, J.I., 1978. Geologia dos sedimentos Fanerozóicos do Estado da Bahia. In: Inda, H.A.V. (Ed.), Geologia e Recursos Minerais do Estado da Bahia. Secretaria das Minas e Energia 1, Textos Básicos, pp. 23-74.

Gierlowski-Kordesch, E.H., 2010. Lacustrine carbonates. In: Alonso-Zarza, A.M., Tanner, L.H. (Eds.), Carbonates in Continental Settings: Facies, Environments and Processes. Elsevier, pp. 1-101.

Hashimoto, A.T., Appi, C.J., Soldan, A.L., Cerqueira, J.L., 1987. O neo-Alagoas nas bacias do Ceará, Araripe e Potiguar (Brasil): caracterização estratigráfica e paleoambiental. Revista Brasileira de Geociências 17, 118-122.

Japsen, P., Bonow, J.M., Green, P.F., Cobbold, P.R., Chiossi, D., Lilletveit, R., Magnavita, L.P., Pedreira, A., 2012. Episodic burial and exhumation in NE Brazil after opening of the South Atlantic. GSA Bulletin 124, 800-816.

Jorgensen, B.B., 1977. The sulfur cycle of a coastal marine sediment (Limfjorden, Denmark). Limnology and Oceanography 22, 814-832.

Karner, G.D., Egan, S.S., Weissel, J.K., 1992. Modeling the tectonic development of the Tucano and Sergipe-Alagoas rift basins, Brazil. Tectonophysics 215, $133-160$.

Karner, G.D., Driscoll, N.W., Barker, D.H.N., 2003. Syn-rift regional subsidence across the West African continental margin: the role of lower plate ductile extension. In: Geological Society, London, Special Publications 207, pp. 105-129.

Lima, M.R., Perinotto, J.A.J., 1984. Palinologia de sedimentos da parte superior da Formação Missão Velha, Bacia do Araripe. Geociências 3, 67-76.

Lima, C.C.U., Vilas Boas, G.S., 2000. A arquitetura deposicional da Formação Marizal (Cretáceo Inferior) na Bacia do Recôncavo, Bahia. Revista Brasileira de Geociências 30, 729-736.

Mabesoone, J.M., Tinoco, I.M., 1973. Paleoecology of Aptian Santana Formation (Northeastern Brazil). Palaeogeography, Palaeoclimatology, Palaeoecology 14, 87-118.

Magnavita, L.P., Davison, I., Kusznir, N.J., 1994. Rifting, erosion, and uplift history of the Recôncavo-Tucano-Jatobá Rift, northeast Brazil. Tectonics 13, $367-388$

Makarkin, V.N., Menon, F., 2005. New species of the Mesochrysopidae (Insecta, Neuroptera) from the Crato Formation of Brazil (Lower Cretaceous), with taxonomic treatment of the family. Cretaceous Research 26, 801-812.

Martill, D.M., Bechly, G., Loveridge, R.F., 2007a. The Crato Fossil beds of Brazil Window into an Ancient World, first ed. Cambridge University Press, New York, p. 625 .

Martill, D.M., Loveridge, R., Heimhofer, U., 2007b. Halite pseudomorphs in the Crato Formation (Early Cretaceous, Late AptianeEarly Albian), Araripe Basin, northeast Brazil: further evidence for hypersalinity. Cretaceous Research 28, 613-620.

Melo Jr., J.L., Oliveira, P.E., 1939. Novas localidades fossilíferas do nordeste da Baia. Departamento Nacional da Produção Mineral, Divisao de Geologia e Mineralogia, Boletim 103 1-69.

Mohr, B.A.R., Eklund, H., 2003. Araripiaflorifera, a magnoliid angiosperm from the Lower Cretaceous Crato Formation (Brazil). Review of Palaeobotany and Palynology 126, 279-292.

Neumann, V.H.M.L., 1999. Estratigrafía, Sedimentología, Geoquímica y Diagénesis de los Sistemas Lacustres Aptiense-Albienses de la Cuenca de Araripe (Noreste de Brasil). Facultat de Geologia, Universitat de Barcelona. Tese de Doctorado, 250 pp.

Neumann, V.H., Rocha, D.E., 2014. Stratigraphy of the Post-Rift Sequences of the Jatobá Basin, Northeastern Brazil, STRATI 2013. Springer, pp. 553-557.

Neumann, V., Rocha, D., Moraes, A., Sial, A., Castro, M.T., Barbosa, J., Fambrini, G., Carvalho, R., 2010. Microfácies carbonáticas e comportamento isotópico de C e O nos calcários laminados aptianos lacustres da Serra Negra, Bacia do Jatobá, Nordeste do Brasil. Estudos Geológicos 20, 89-100.

Paz, J.D.S., Rossetti, D.F., 2006. Paleohydrology of an Upper Aptian lacustrine system from northeastern Brazil: integration of facies and isotopic geochemistry. Palaeogeography, Palaeoclimatology, Palaeoecology 241, 247-266.

Paz, J.D.S., Rossetti, D.F., Macambira, J.B., 2005. An Upper Aptian saline pan/lake system from the Brazilian equatorial margin: integration of facies isotopes. Sedimentology 52, 1303-1321.

Perry, R.S., McLoughlin, N., Lynne, B.Y., Sephton, M.A., Oliver, J.D., Perry, C.C., Campbell, K., Engel, M.H., Farmer, J.D., Brasier, M.D., Staley, J.T., 2007. Defining biominerals and organominerals: direct and indirect indicators of life. Sedimentary Geology 201, 157-179.

Peulvast, J.-P., Sales, V.C., Bétard, F., Gunnell, Y., 2008. Low post-Cenomanian denudation depths across the Brazilian Northeast: implications for long-term landscape evolution at a transform continental margin. Global and Planetary Change 62, 39-60.

Quijada, I.E., Suarez-Gonzalez, P., Benito, M.I., Mas, R., 2013. Depositional depth of laminated carbonate deposits: insights from the Lower Cretaceous Valdeprado Formation (Cameros Basin, Northern Spain). Journal of Sedimentary Research 83, 241-257.

Regali, M.S.P., 2000. Indicação de Ambiente Marinho Marginal na Bacia de Tucano: Formação Marizal, Neoaptiano, Bahia - Brasil. Paleo 2000, Resumos, 141.

Reis, M.A.F., 2007. A fauna de invertebrados f6sseis da Formação Marizal da Bacia de Tucano, Cretáceo Inferior do Nordeste do Brasil: Considerações sistemáticas. In: Carvalho, I.S., Cassab, R.C.T., Schwanke, C., Carvalho, M.A., Fernandes, A.C.S., Rodrigues, M.A.C., Carvalho, M.S.S., Arai, M., Oliveira, M.E.Q. (Eds.), Paleontologia: Cenarios de Vida, 1. Editora Interciencia, Rio de Janeiro, pp. $433-441$.

Renault, R.W., Gierlowski-Kordesch, E.H., 2010. Lakes. In: James, N.P. (Ed.), Facies Models 4. Geological Association of Canada. St. John's, Newfoundland, pp. $541-575$.

Riding, R., 2000. Microbial carbonates: the geological record of calcified bacterial-algal mats and biofilms. Sedimentology 47, 179-214.

Rodriguez-Pascua, M.A., Calvo, J.P., De Vicente, G., Gómez-Gras, D., 2000. Softsediment deformation structures interpreted as seismites in lacustrine sediments of the Prebetic Zone, SE Spain, and their potential use as indicators of earthquake magnitudes during the Late Miocene. Sedimentary Geology 135, $117-135$.

Rolim, J.L., 1984. Estudo da sequência clástica e carbonática da Serra do Tonã Macururé, Estado da Bahia. Universidade Federal do Rio Grande do Sul, Porto Alegre, p. 155.

Rossetti, D.F., Paz, J.D.S., Góes, A.M., 2004. Facies analysis of the Codó Formation (Late Aptian) in the Grajaú Area, Southern São Luís-Grajaú Basin. Anais da Academia Brasileira de Ciências 76, 791-806.

Roxo, M.G.O., 1940. Preliminary note on fossil crustacea from Bahia, Brazil. Anais da Academia Brasileira de Ciências 4, 279-280.

Santos, F.N., Brito, P.M., 2005. Primeira ocorrência do filo Mollusca na Formação Marizal, Cretáceo Inferior de Tucano, Bahia. Encontro Brasileiro de Malacologia, Rio de Janeiro, SBMa, 279.

Scherer, C.M.S., Goldberg, K., Bardola, T., 2015. Facies architecture and sequence stratigraphy of an early post-rift fluvial succession, Aptian Barbalha Formation, Araripe Basin, northeastern Brazil. Sedimentary Geology 322, 43-62.

Silva, A.L., Neumann, V.H., 2003. Formação Crato da Bacia do Araripe: um reservatório análogo ao calcário Trairí (Formação Paracuru), Bacia do Ceará, $2^{\circ}$ Congresso Brasileiro de P\&D em Petróleo \& Gás. Rio de Janeiro- RJ.

Silva Santos, R., 1972. Peixes da Formação Marizal, Estado da Bahia, Instituto de Geociências. Universidade de São Paulo, São Paulo, p. 76.

Silva Santos, R., 1973. Paleoictiofáunula da Formação Marizal, Estado da Bahia. Congresso Brasileiro de Geologia 27, 136.

Silva Santos, R., 1976. Sobre a presença do gênero Clupavus no Cretáceo Inferior do Brasil. Anais da Academia Brasileira de Ciências 48, 359.

Silva Santos, R., 1985. Clupavus brasiliensis n. sp. (Teleostei, Clupeiformes) do Cretáceo inferior - Formação Marizal, Estado da Bahia. Departamento Nacional da Produção Mineral, Coletânea de Trabalhos Paleontológicos 155-159.

Silva Santos, R., 1990. Vinctifer longirostris, do Cretáceo inferior da Formação Marizal, Estado da Bahia, Brasil. Anais da Academia Brasileira de Ciências 62, $251-260$

Silveira, A.C., Varejão, F.G., Neumann, V.H., Sial, A.N., Assine, M.L., Ferreira, V.P., Fambrini, G.L., 2014. Quimioestratigrafia de Carbono e Oigênio dos Carbonatos Lacustres Aptianos da Serra do Tonã, sub-Bacia de Tucano Norte, NE do Brasil. Estudos Geológicos 24, 47-63.

Spigolon, A.L.D., Lewan, M.D., de Barros Penteado, H.L., Coutinho, L.F.C., Mendonça Filho, J.G., 2015. Evaluation of the petroleum composition and quality with increasing thermal maturity as simulated by hydrous pyrolysis: a case study using a Brazilian source rock with Type I kerogen. Organic Geochemistry 83-84, 27-53.

Tye, R.S., Coleman, J.M., 1989. Depositional processes and stratigraphy of fluvially dominated lacustrine deltas: Mississipi delta plain. Journal of Sedimentary Research 59, 973-996.

Viana, C.F., Gama Jr., E.G., Simões, I.A., Moura, J.A., Fonseca, J.R., Alves, R.J., 1971 Revisão Estratigráfica da Bacia Recôncavo/Tucano. Boletim Técnico da Petrobrás 14, 157-192. 